\title{
Source attribution of cloud condensation nuclei and their impact on stratocumulus clouds and radiation in the south-eastern Atlantic
}

Haochi Che ${ }^{1, \text { a }}$, Philip Stier ${ }^{1}$, Duncan Watson-Parris ${ }^{1}$, Hamish Gordon ${ }^{2, \mathrm{~b}}$, Lucia Deaconu ${ }^{1, \mathrm{c}}$

${ }^{1}$ Atmospheric, Oceanic and Planetary Physics, Department of Physics, University of Oxford, Oxford, OX1 3PU, UK

$5 \quad{ }^{2}$ School of Earth and Environment, University of Leeds, LS2 9JT, UK

${ }^{a}$ now at: Department of Geophysics, Tel-Aviv University, 69978, Israel

bnow at: Engineering Research Accelerator, Carnegie Mellon University, Pittsburgh, PA 15217, United States

'now at: Faculty of Environmental Science and Engineering, Babeș-Bolyai University, Cluj-Napoca, 400294, Romania

Correspondence to: Haochi Che (haochiche@tauex.tau.ac.il)

10 Abstract The semi-permanent stratocumulus clouds over the South-eastern Atlantic Ocean (SEA) can act as an "air conditioners" to the regional and global climate system. The interaction of aerosols and clouds become important in this region, and can lead to negative radiative effects, partially offsetting the positive radiative forcing of greenhouse gases. A key pathway of aerosols affecting cloud properties is by acting as cloud condensation nuclei (CCN). In this paper, we use the United Kingdom Earth System Model to investigate the sources of CCN (from atmospheric processes and emission sources) in the

15 SEA, and the response of cloud droplet number concentration (CDNC), cloud liquid water path (LWP), and radiative forcing to those sources. Overall, total nucleation (binary nucleation) is the most important source of $\mathrm{CCN}_{0.2 \%}$ in the marine boundary layer, contributing an annual average of $50 \%$ of $\mathrm{CCN}_{0.2 \%}$. In terms of emission sources, anthropogenic emissions (from energy, industry, agriculture, etc.) contribute the most to the annual average $\mathrm{CCN}_{0.2 \%}$ in the marine boundary layer, followed by $\mathrm{BB}$. In the free troposphere, however, $\mathrm{BB}$ becomes the dominant source of $\mathrm{CCN}_{0.2 \%}$, accounting for $64 \%$ of the annual average.

20 The contribution of aerosols from different sources to $\mathrm{CDNC}$ is consistent with their contribution to $\mathrm{CCN}_{0.2 \%}$ within the marine boundary layer, with total nucleation being the most important source of CDNC overall. In terms of emissions, anthropogenic sources are also the largest contributors to the annual average of CDNC, closely followed by BB. The contribution of BB to $\mathrm{CDNC}$ is more significant than its increase to $\mathrm{CCN}_{0.2 \%}$, mainly because $\mathrm{BB}$ aerosol also can increase $\mathrm{CDNC}$ by enhancing the maximum supersaturation through the radiative effect of shortwave absorption. For an aerosol source that shows an increase

25 in CDNC, it also shows an increase in LWP resulting from a reduction in autoconversion. BB aerosol, due to the absorption effect, can enhance existing temperature inversions and reduce the entrainment of sub-saturated air, leading to a further increase in LWP. As a result, the contribution of BB to LWP is second only to total nucleation. These findings demonstrate that BB is not the dominant source of $\mathrm{CCN}$ within the marine boundary layer from an emission source perspective. However, its contribution to clouds increases due to its absorption effect (about the same as anthropogenic sources for CDNC and more than anthropogenic sources for LWP), highlighting the crucial role of its radiative effect on clouds. The results on the radiative 
effects of aerosols show that $\mathrm{BB}$ aerosol exhibits an overall positive $\mathrm{RF}_{\text {ari }}$ (radiative forcing associated with aerosol-radiation interaction), but its net effective radiative forcing remains negative due to its effect on clouds (mainly by absorbing effect). By quantifying aerosol and cloud properties affected by different sources, this paper provides a framework to understand aerosol sources effects on the marine cirrocumulus clouds and radiation in the SEA.

\section{Introduction}

Marine stratocumulus clouds cover approximately one-quarter of the ocean surface in the annual mean (Hahn and Warren, 2007), resulting in a strong negative net radiative effect that significantly affects climate, therefore referred to as "air conditioners" to the climate system (Stephens and Slingo, 1992). Stratocumulus clouds in the South-eastern Atlantic Ocean (SEA) are one of the most extensive stratocumulus cloud decks on the planet (Wood, 2012) and semi-permanently present off the coast of Africa. The interaction of aerosol-cloud becomes extremely important in this region, as a moderate change in the cloud coverage or liquid water path induced by aerosol could compensate the radiative forcing of greenhouse gases and significantly affect the regional or global climate (Wood, 2012). A key pathway of aerosol effects on cloud properties is by acting as cloud condensation nuclei (CCN). The increased CCN from different sources can alter the liquid water path (LWP) by affecting the cloud state (Berner et al., 2015) and cloud lifetime (Ackerman et al., 2004). At a fixed LWP, the increased

$15 \mathrm{CCN}$ due to emission perturbations leads to the increase of cloud droplet concentrations of smaller radii and subsequently to an increase of cloud albedo, commonly referred to as the radiative forcing associated with aerosol-cloud interaction, i.e. $\mathrm{RF}_{\text {aci }}$ (Twomey, 1974). The increased CCN can also trigger rapid adjustments, affecting the cloud lifetime and precipitation (Albrecht, 1989). Under the combined effects of these two ( $\mathrm{RF}_{\text {aci }}$ and rapid adjustments), referred to as ERF aci, aerosol-cloud interactions represent one of the largest sources of uncertainties in future climate projections (Boucher et al., 2013).

In the SEA, the persistent stratocumulus cloud deck encounters particles from various sources. Among them, biomass burning (BB) aerosol, advected from continental Africa, where one-third of the global BB emissions are produced through July to October (Roberts et al., 2009; van der Werf et al., 2010), plays a unique role in modulating the cloud properties due to its shortwave absorption ability as well as acting as CCN. Previous studies suggest that the radiative effect of BB aerosol acts to

25 strengthen the capping inversion and thereby the underlying LWP, with significant impacts on the radiation balance (Ackerman et al., 2004; Deaconu et al., 2019; Gordon et al., 2018; Wilcox, 2010). CCN from BB can plays an important role in affecting stratocumulus cloud droplet concentration and the radiative forcing (Lu et al., 2018). However, there exists no consensus on the importance of BB aerosol in acting as CCN (Che et al., 2021; Gordon et al., 2018; Lu et al., 2018; Mallet et al., 2020) in the SEA, mainly because the fraction of BB aerosol entering the marine boundary layer remains uncertain. Sea-salt aerosol is

30 one of the largest contributors of global primary aerosols in terms of mass concentration (Seinfeld and Pandis, 1998). Although its particles can be easily activated due to their high hygroscopicity, the contribution of sea-salt aerosol to the marine $\mathrm{CCN}$ 
population and its relative importance in indirect effects over the ocean is uncertain (Tsigaridis et al., 2013). Some studies report sea-salt aerosol as the primary source of CCN over the ocean (e.g. Pierce and Adams, 2006), while other studies found sea-salt only contributes a small fraction of marine CCN (Quinn et al., 2017). Besides sea salt, marine emissions are also the primary source of dimethyl sulfide (DMS), which produces the largest fraction of natural sulfur species in the atmosphere via oxidation (Andreae, 1990). The oxidation products of DMS (methanesulfonic acid and $\mathrm{H}_{2} \mathrm{SO}_{4}$ ) can form new particles via multiple nucleation processes (i.e., binary, ternary, and ion-induced) or condense onto existing particles and eventually form CCN (e.g., Lee et al., 2003). CCN from DMS is crucial for marine boundary layer clouds and is often found to have a key role in the clean and low wind marine environment (Sanchez et al., 2018), resulting in profound climate implications (Charlson et al., 1987; Thomas et al., 2010). With the development of the African economy, anthropogenic emissions of energy, industrial,

10 agriculture etc., are expected to increase significantly and could have a similar magnitude to the African biomass burning around 2030 (Liousse et al., 2014). Many studies have concluded that anthropogenic aerosols are generally hygroscopic and responsible for the increase of global CCN (Che et al., 2017; Rose et al., 2011; Schmale et al., 2018; Yu et al., 2013). In the SEA, most anthropogenic and BB aerosols are advected from continental Africa and can activate to cloud droplets after entraining clouds. However, even under a similar amount of advected concentration, these two types of aerosols may contribute

15 differently to the number of activated droplets in the stratocumulus clouds layer due to their different abilities in affecting the atmosphere temperature profile. Another potentially important source of CCN in the SEA is dust, as this area is well within the dispersion of the Kalahari dust air masses (Bhattachan et al., 2012). In-situ measurements found dust is one of the most observed aerosols at Ascension Island (Schenkels, 2018; Swap et al., 1996), indicating dust particles are able to transport through the stratocumulus cloud deck. Although insoluble, wettable dust particles with large diameters can act as CCN, while

20 small dust particles can accumulate soluble materials through internal mixing during transportation, and dramatically increase its ability to activation (Bègue et al., 2015; Dusek et al., 2006; Gibson et al., 2007; Hatch et al., 2008). Bègue et al. (2015) found that Saharan aged dust can even account for more than $70 \%$ of the $\mathrm{CCN}$ during their measurement in the Netherlands, confirming the significant role of aged dust particles in acting as $\mathrm{CCN}$.

25 Apart from primary emissions, a large fraction of atmospheric aerosols, known as secondary aerosols, are formed from atmospheric processes (oxidation of gaseous precursors, i.e., nucleation) and can serve as $\mathrm{CCN}$ after the subsequent growth of nucleated clusters to sufficiently larger sizes (Kerminen et al., 2012; Merikanto et al., 2009). Studies have found that the nucleation of aerosols in the boundary layer and free troposphere is the dominant source of particle number in the atmosphere (Kulmala et al., 2004; Kulmala and Kerminen, 2008). However, the contribution of nucleation to CCN is not consistent, as 30 some studies found that less than $10 \%$ of nucleated particles can grow to diameters of $100 \mathrm{~nm}$ in general (Kuang et al., 2009; Westervelt et al., 2013), implying the potentially limited role of nucleation in providing CCN. However, several studies have shown that small particles generated by nucleation in the free troposphere can grow with subsidence and contribute most of the $\mathrm{CCN}$ within the marine boundary layer, resulting in more than half of the $\mathrm{CCN}$ in the global marine boundary layer coming from nucleation (Clarke et al., 2013; Merikanto et al., 2009; Williamson et al., 2019; Clarke and Kapustin, 2002). Therefore, 
the role of nucleation in affecting stratocumulus cloud deck in SEA remains uncertain, hindering our understanding of the aerosol-cloud interactions in this region.

Two aircraft observation campaigns were performed during the BB season in the SEA to enable an intensive study of the

5 aerosols and clouds interactions in this region. Those two campaigns flew different areas in the SEA, where the NASA ORACLES (ObseRvations of Aerosols above CLouds and their intEractionS) was lunched from Walvis Bay (Namibia) in 2016 and from Sao Tomé in 2017 (Redemann et al., 2021); CLARIFY (CLoud-Aerosol-Radiation Interaction and Forcing: Year 2017) flew around Ascension Island and can provide information on aerosol-cloud-radiation interactions in the region where stratocumulus to cumulus transition occurs (Haywood et al., 2021). The main focus of these two flight campaigns is BB

10 aerosols and their effects on clouds; however, due to the complexity of the aerosol sources, the contribution of BB to the CCN remains unclear. Here we use United Kingdom Earth System Model, UKESM1(Sellar et al., 2019) to investigate the source attribution of $\mathrm{CCN}$ in the SEA, contributing to the understanding of the main sources of CCN in this region. The model has previously been evaluated with data from ORACLES and CLARIFY observations and the results show that it provides a good simulation of the spatial and vertical distribution of aerosols (Che et al., 2021). The subsequent cloud droplet concentration,

15 cloud liquid water and radiative forcing associated with different sources are also investigated. The article is structured as follows. Section 2 presents the method, and results are listed in section 3. In section 3.1, we investigate the vertical distribution of CCN contributed by emissions and atmospheric processes, as well as the mean concentrations of CCN in different layers. Section 3.2 examines the cloud adjustments by aerosols from different sources, including CDNC and LWP. Section 3.3 shows radiative forcings associated with those aerosols. Then section 4 contains conclusions and discussions.

\section{Method}

\subsection{Model configuration}

The first version of the United Kingdom Earth System Model, UKESM1(Sellar et al., 2019), has been jointly developed by the UK's Met Office and Natural Environment Research Council (NERC). The core of UKESM1 is based on the Hadley Centre Global Environmental Model version 3 (HadGEM3) Global Coupled (GC) climate configuration of the Unified Model

25 (UM) (Hewitt et al., 2011). The atmospheric part of the model is configured as Global Atmosphere 7.1 (GA7.1). Aerosol and its interactions with clouds are represented by the UK Chemistry and Aerosol model (UKCA) (Mulcahy et al., 2020; O'Connor et al., 2014). Differing from the standard configuration of representing the dust size distribution as six bins (Woodward, 2001), our configuration uses seven interactive log-normal aerosol modes in the microphysics scheme GLOMAP (Mann et al., 2010), comprising sulfate, sea salt, black carbon, organic carbon and dust. The $\kappa$-Kohler activation scheme is implemented, which

30 use a hygroscopicity parameter of each aerosol mode, $\kappa$, to calculate the activated CCN. The $\kappa$ value is set as $0.6,0.2$, and 1.2 for sulfate, organic, and sea-salt, respectively, and 0 for black carbon and dust (Engelhart et al., 2012; Petters and Kreidenweis, 
2007). The internal volume mixing rule (Petters and Kreidenweis, 2007) is used to calculate the mean hygroscopicity of each mode. The Coupled Model Intercomparison Project Phase 6 (CMIP6) emission data in 2014 is used (Eyring et al., 2016; Gidden et al., 2019). Due to the high interannual variability of BB emission, the global fire assimilation system (GFAS) version 1 data based on satellite fire monitoring is employed with a scaling factor of 2 (Johnson et al., 2016). A more detailed 5 description can be found in our previous paper (Che et al., 2021).

The GFAS biomass burning and CMIP6 2014 emissions are used as the baseline simulation. To facilitate our source attribution, four additional runs are made with BB, dust, sea-salt, and DMS emission turned off, and one simulation with pre-industrial CMIP6 emissions. Note that although black carbon (BC) and organic carbon (OC) are the main components of BB emissions,

10 these two types of aerosols are also available in anthropogenic emissions. However, BC and OC from anthropogenic emissions are mainly from fossil fuels and biofuels, and the emission sectors for them are energy, industrial, shipping, transportation, solvents, waste, agriculture, and residential. In comparison, $\mathrm{BC}$ and $\mathrm{OC}$ from $\mathrm{BB}$ are mainly emitted from the burning of agricultural, peat, savanna, forest, and deforestation. In addition to these aerosols associated emission sources, three additional runs are performed without SOA (secondary organic aerosol) formation, boundary layer nucleation, and total nucleation, to

15 allow attribution to atmospheric processes. Precursors for nucleation include $\mathrm{H}_{2} \mathrm{SO}_{4}$, which is contained in both natural and anthropogenic emissions. Therefore, the nucleation can also be affected by these emissions. The boundary nucleation scheme is based on the organic-mediated nucleation (Metzger et al., 2010), determined by the concentrations of sulfuric acid and SOA, and limited to the boundary layer. The total nucleation includes the boundary layer nucleation and homogeneous binary nucleation of sulphuric acid and water, which is applicable to both tropospheric and stratospheric conditions, as described in

20 Vehkamäki et al. (2002). The gas-phase oxidations of Monoterpene by $\mathrm{OH}, \mathrm{O}_{3}$, and $\mathrm{NO}_{3}$ yield $\mathrm{SOA}$ at a fixed rate of 0.26 , which is scaled by 2 from the original value based on alpha-pinene (Spracklen et al., 2006) to compensate for the missing SOA from other sources. The resolution of our simulations is N96, i.e., $1.875^{\circ} \times 1.25^{\circ}$, with 85 vertical levels. Sea surface temperatures and sea ice are prescribed with daily reanalysis data (Reynolds et al., 2007). In all runs, horizontal wind fields above $1500 \mathrm{~m}$ are nudged every $6 \mathrm{~h}$ with ERA-Interim data (Telford et al., 2008), while the temperature is free-run to allow fast adjustments, following the recommendations of Zhang et al. (2014). 


\subsection{Investigated area and time period}
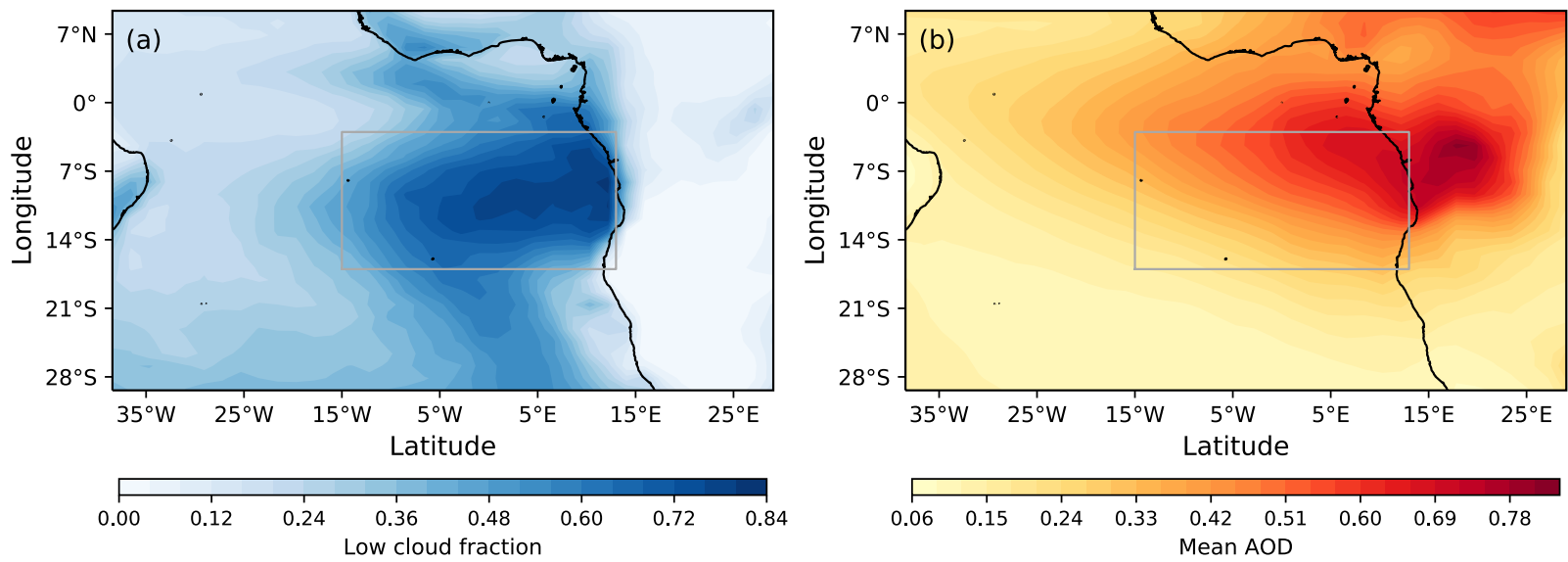

Figure 1. UKESM1 simulated mean (a) low-level cloud fraction and (b) aerosol optical depth from July to September of 2016 and 2017. The domain, ranging from $30^{\circ} \mathrm{S}$ to $10^{\circ} \mathrm{N}$ and from $40^{\circ} \mathrm{W}$ to $30^{\circ} \mathrm{E}$, is the area this paper interested in. The grey box (cloud box) in the map represents the area where the average low cloud fraction is above 0.6.

The model runs from 2016 to 2017 to overlap with the ORACLES and CLARIFY flights campaigns conducted in the SEA. July, August and September of the two years are selected to represent the BB season, as the highest mean AOD associated with $\mathrm{BB}$ are found in these months. The low-level cloud fraction during the BB season is higher than the annual average, indicating the co-existence of the intensive stratocumulus cloud deck and BB plume in the SEA. Figure 1 shows the mean low cloud fraction and AOD during BB season. In addition to the illustrated domain representing the SEA region in the figure, a small area is identified as the cloud box region, with the fraction of low-level clouds 0.6 for BB season mean and 0.5 for the two-year average. The location and size of the cloud box region are different from the one identified by Klein and Hartmann (1993), as we encompass stratocumulus and cumulus clouds. Despite the border of our defined area, the annual mean of low

15 cloud fraction is 0.5 in the cloud box, indicating the semi-permanent feature of low clouds in this region. The mean AOD in the cloud box region is 0.43 and 0.26 for the $\mathrm{BB}$ season and the two-year averages separately. $\mathrm{BB}$ aerosol contributes around $76 \%$ of total AOD in the cloud box during BB season, implying the potentially dominant role of BB aerosol in affecting CCN and cloud that motivated the ORACLES/CLARIFY campaigns. However, as most of the BB aerosol is above the stratocumulus cloud deck (figure 2), combined with its low hygroscopicity, the fraction of BB aerosol to activate as cloud droplets is uncertain. 


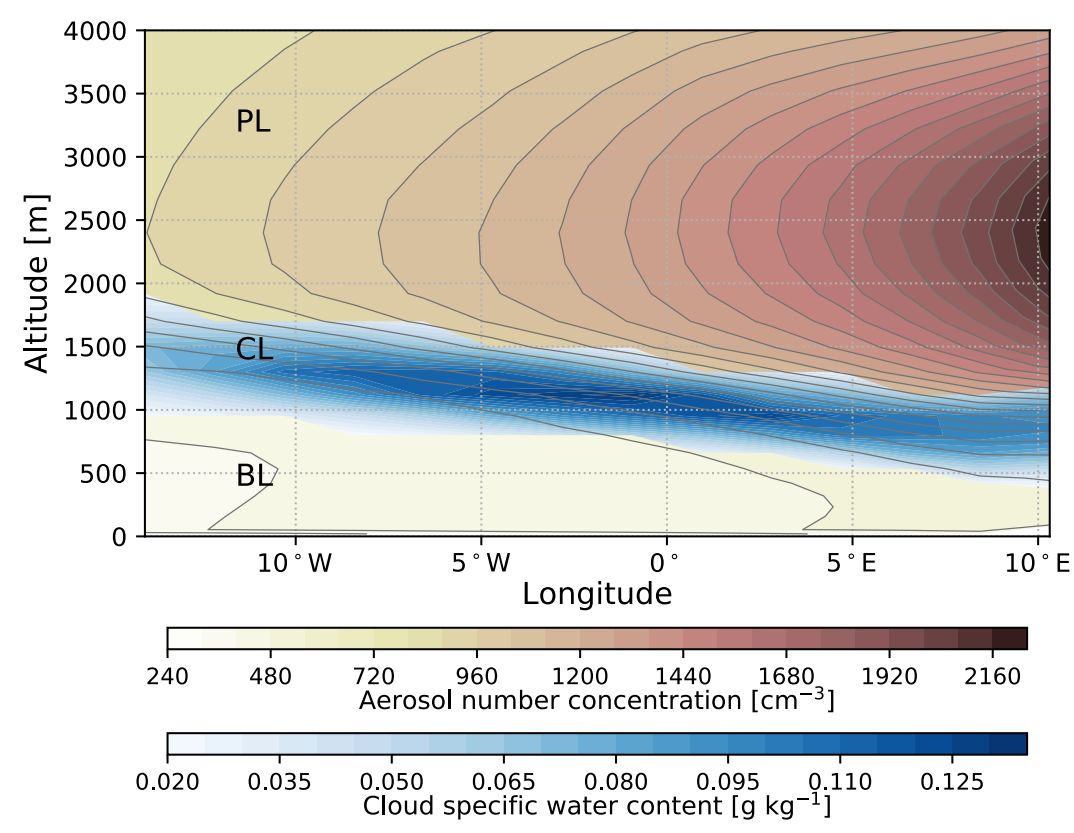

Figure 2. UKESM1 simulated mean vertical profiles of cloud specific water content $(\mathrm{g} / \mathrm{kg})$ and aerosol number concentration $\left(\mathrm{cm}^{-3}\right)$ at the standard temperature and pressure (STP) in the cloud box region during BB season. The BL, CL, and PL represent the boundary layer, cloud layer, and plume layer, respectively. The cloud layer is identified as the layer with specific liquid 5 water content $>0.02 \mathrm{~g} / \mathrm{kg}$.

The mean vertical profiles of cloud liquid water content and aerosol number concentration in the cloud box during BB season are illustrated in figure 2. Three layers are defined to investigate source attributed $\mathrm{CCN}$ in different areas. The cloud layer (CL), where liquid water content is above $0.02 \mathrm{~g} / \mathrm{kg}$, represents the semi-permanent stratocumulus cloud deck. We define the 10 area below the cloud layer as the boundary layer (BL), and above the plume layer (PL). As shown in figure 2, most aerosols emanating from the continent are located in the plume layer, with a maximum concentration at the height of around $2500 \mathrm{~m}$. The boundary layer has the lowest aerosol concentration. This may be because only a small proportion of aerosols can enter the cloud layer from the top, and the fraction of aerosols that could enter the boundary layer is further reduced by the cloud wet scavenging process (Textor et al., 2006). Therefore, the boundary is relatively clean, with the aerosol concentration around

15 a few hundred per cubic centimetre. However, as the boundary layer is close to the sea surface, it may have a larger fraction of sea-salt aerosols. The annual mean vertical profiles of liquid water content and aerosol number concentration in the cloud box have a similar pattern, with a lower concentration of aerosols and cloud liquid water (Figure S1 in supplement). 
The model has been evaluated with the ORACLES $(2016,2017)$ and CLARIFY measurements by examining the collocated aerosol extinction in our previous paper. The result shows the model can generally capture the spatial and vertical distributions of BB plume (Che et al., 2021). This result provides confidence in this source attribution of aerosols in the SEA.

\section{Results}

\section{$5 \quad 3.1$ Cloud condensation nuclei concentration}

\subsubsection{Vertical distribution of $\mathrm{CCN}$}

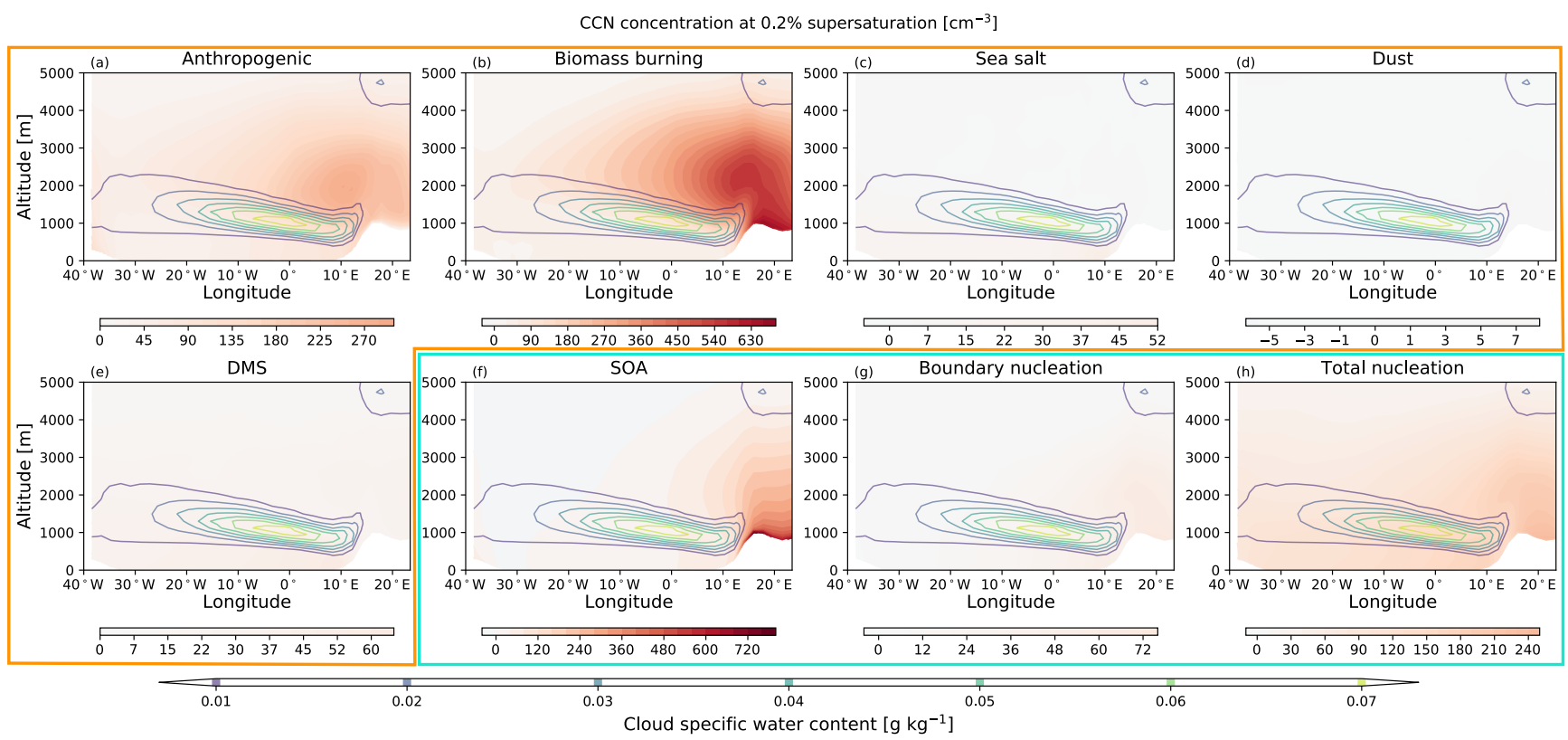

Figure 3. UKESM1 simulated annual mean vertical profiles of $\mathrm{CCN}$ concentration at $0.2 \%$ supersaturation $\left(\mathrm{CCN}_{0.2 \%}\right)$ from different sources (at the standard temperature and pressure STP). Profiles are averaged along the latitudes of the cloud box.

10 The contributions of different sources to $\mathrm{CCN}_{0.2 \%}$ are listed in (a) to (h), where the contribution of emissions is shown in the yellow frame, and the contribution of atmospheric processes is shown in the light blue frame. The contour lines in each subplot are the cloud specific water content from the baseline simulation at the same temporal and spatial average. The same colourmap scale is used in each subplot to facilitate comparison, but the range differs for each plot, corresponding to the maximum and minimum of $\mathrm{CCN}_{0.2 \%}$.

The annual mean profiles of $\mathrm{CCN}_{0.2 \%}$ ( $\mathrm{CCN}$ at $0.2 \%$ supersaturation) concentration from different sources are illustrated in Fig. 3. Overall, $\mathrm{BB}$ is the dominant source of $\mathrm{CCN}_{0.2 \%}$, although its contribution is mainly distributed above the cloud layer. 
This is because BB aerosol is emitted from the continent and therefore mainly located in the free troposphere in its westward transport. Anthropogenic aerosol, also originated from the land, is the second-largest source of $\mathrm{CCN}_{0.2 \%}$ from emissions in the SEA, while its $\mathrm{CCN}_{0.2 \%}$ concentration is around one-third of that associated with $\mathrm{BB}$ above the cloud. However, when in the cloud layer, these two sources are almost equally important, with the $\mathrm{CCN}_{0.2 \%}$ from $\mathrm{BB}$ being only slightly higher. This may

5 be partly because the short-wave absorption capability of BB aerosol has inhibited the cloud top entrainment when the BB aerosol is above the clouds (Johnson et al., 2004; Sakaeda et al., 2011; Wilcox, 2010), resulting in fewer BB aerosols being able to enter the clouds. Another $\mathrm{CCN}_{0.2 \%}$ source linked strongly with the land is $\mathrm{SOA}$, as monoterpene, the precursor of the SOA in our model, is mostly from plants (Mentel et al., 2009). Marine emissions make a small contribution to monoterpene (Yassaa et al., 2008), contributing to SOA concentrations in the marine boundary layer.

DMS and sea-salt attributed $\mathrm{CCN}_{0.2 \%}$ have low concentrations and are mainly distributed in the marine boundary layer, as they are both emitted from the ocean surface. Although aerosols from these two sources have high hygroscopicity, their low number concentration limited their $\mathrm{CCN}$ number. Dust merely has an impact on the $\mathrm{CCN}_{0.2 \%}$, partly due to the hydrophobic characteristics of its particles as represented in the model, and partly because of the low concentration of dust in this region.

15 For atmospheric processes, both the total and boundary layer nucleation lead to an increase in $\mathrm{CCN}_{0.2 \%}$ concentrations, indicating the contribution of nucleation to $\mathrm{CCN}$. However, their contribution to $\mathrm{CCN}_{0.2 \%}$ is lower than that of $\mathrm{BB}$ and anthropogenic emissions above clouds. Total nucleation contributes more to $\mathrm{CCN}_{0.2 \%}$ compared to boundary layer nucleation, indicating a contribution from the free troposphere. The $\mathrm{CCN}_{0.2 \%}$ mean concentration profiles during the $\mathrm{BB}$ season shows a similar pattern with the annual means (figure $\mathrm{S} 2$ ), while the $\mathrm{CCN}_{0.2 \%}$ concentration associated with $\mathrm{BB}$, anthropogenic emission and SOA is $\sim 2.3,1.8$, and 1.5 times of its annual means, respectively, indicating the significant contribution of BB to CCN. 


\subsubsection{Mean concentration of $\mathrm{CCN}$ at different layers}

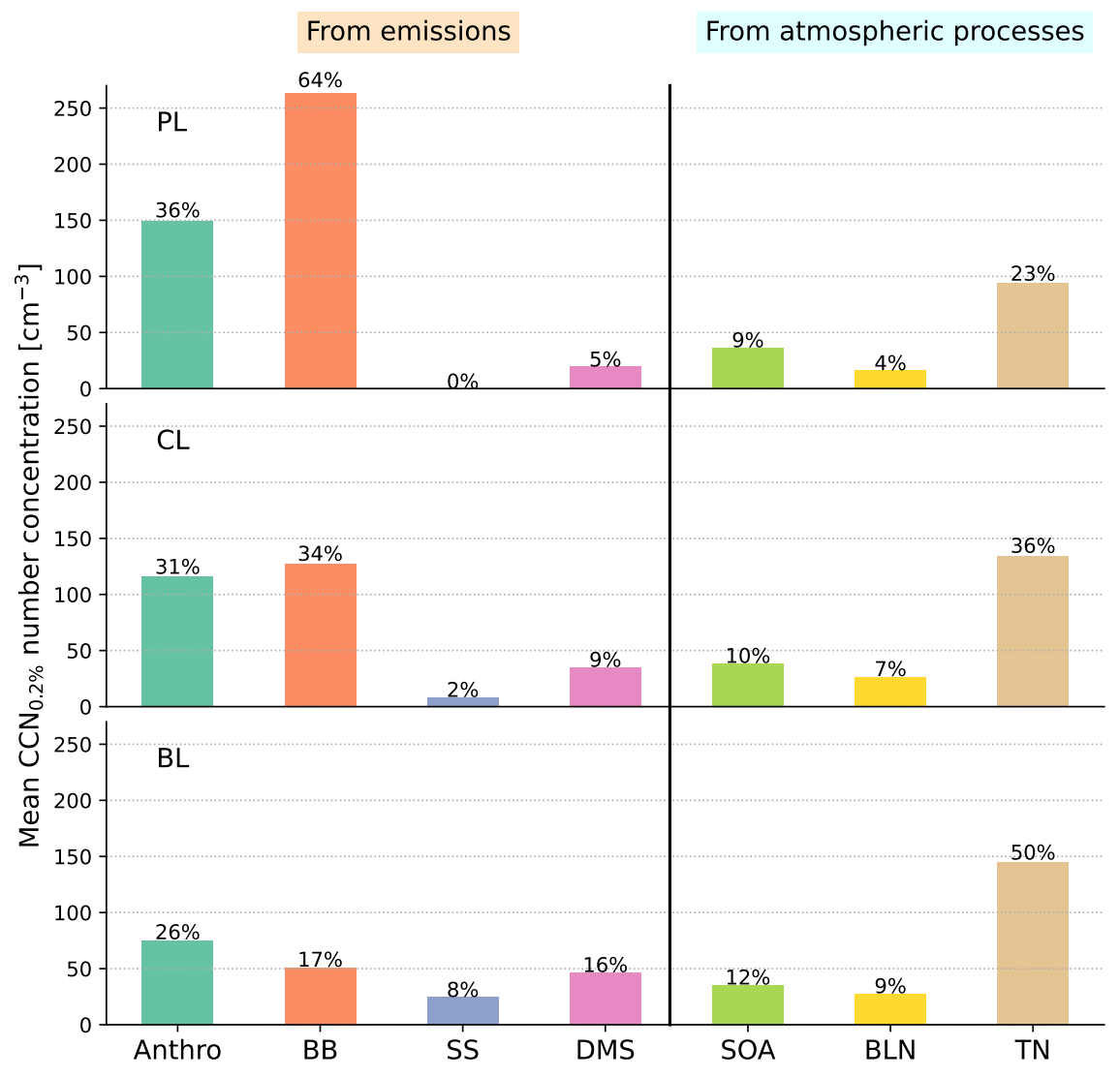

Figure 4. UKESM1 simulated annual mean $\mathrm{CCN}$ concentration at $0.2 \%$ supersaturation $\left(\mathrm{CCN}_{0.2 \%}\right)$ in the cloud box region from different sources and in different layers. The upper, middle, and lower panels represent $\mathrm{CCN}_{0.2 \%}$ attribution in the plume layer (PL), cloud layer (CL), and the marine boundary layer (BL), respectively. The left part of the black vertical line indicates the contribution to $\mathrm{CCN}_{0.2 \%}$ from the emission sources, which are anthropogenic (Anthro), BB, sea salt (SS), and DMS. The right part of the black vertical line indicates the contribution to $\mathrm{CCN}_{0.2 \%}$ from atmospheric processes, which are SOA, boundary layer nucleation (BLN) and total nucleation (TN). Using the simulation of the present day as the baseline, the contribution of each source to $\mathrm{CCN}_{0.2 \%}$ is marked at the top of the corresponding bar in percentage.

The source attribution of $\mathrm{CCN}$ in the cloud box region is investigated in this section. The location and definition of the cloud box region can be found in the methods. Here we also focus on the $\mathrm{CCN}$ concentration at $0.2 \%$ supersaturation, as the maximum supersaturation in the area is usually less than $0.2 \%$ (Che et al., 2021). The annual mean concentrations of $\mathrm{CCN}_{0.2 \%}$ in the cloud box at different layers contributed by different sources are illustrated in figure 4 . The contribution to $\mathrm{CCN}_{0.2 \%}$ from 
different emissions is shown on the left of the black vertical line, while the contribution to $\mathrm{CCN}_{0.2 \%}$ from atmospheric processes is on the right. As can be seen from the figure, overall, the most important source of $\mathrm{CCN}_{0.2 \%}$ in the marine boundary layer (BL) is total nucleation. This is evident in both two-year and the BB season averages (Fig. S3), suggesting that the subsidence and growth of free-tropospheric nucleated aerosols contribute significantly to the $\mathrm{CCN}$ in the marine boundary layer. The

5 frequent new particle formation events may be explained by the low aerosol concentrations in the marine boundary layer in this region, as the annual and $\mathrm{BB}$ seasonal means of $\mathrm{CCN}_{0.2 \%}$ are $331 \mathrm{~cm}^{-3}$ and $290 \mathrm{~cm}^{-3}$. The boundary layer nucleation contributes about $9 \%$ of the $\mathrm{CCN}_{0.2 \%}$ in the marine boundary layer, about one-fifth of the $\mathrm{CCN}_{0.2 \%}$ of the total nuclei. This may be because the boundary nucleation scheme is based on organic-mediated nucleation (Metzger et al., 2010), determined by the concentrations of sulphuric acid and SOA. While the total nucleation includes homogeneous binary nucleation of sulphuric acid and water, which applies to both tropospheric and stratospheric conditions, as described in Vehkamäki et al. (2002).

In terms of emission sources, anthropogenic emissions are the largest source of $\mathrm{CCN}_{0.2 \%}$ within the marine boundary layer, in both annual and $\mathrm{BB}$ seasonal averages. $\mathrm{BB}$ is the second largest contributor to $\mathrm{CCN}_{0.2 \%}$ within the marine boundary layer from emissions, accounting for $17 \%$ and $19 \%$ of $\mathrm{CCN}_{0.2 \%}$ in annual and $\mathrm{BB}$ seasonal averages. Although $\mathrm{BB}$ aerosols strongly influence this region, the contribution of anthropogenic sources to the $\mathrm{CCN}_{0.2 \%}$ remains higher within the boundary layer. This may be due to $\mathrm{SO}_{2}$ emitted from anthropogenic sources, which can increase $\mathrm{CCN}_{0.2 \%}$ by nucleation. Since nucleation is an essential source of $\mathrm{CCN}_{0.2 \%}$, nucleation of aerosols due to $\mathrm{SO}_{2}$ from anthropogenic sources may be one of the main ways in which anthropogenic sources increase $\mathrm{CCN}_{0.2 \%}$. The $\mathrm{CCN}_{0.2 \%}$ contributed by sea salt and DMS is mainly concentrated within the marine boundary layer, with $8 \%$ and $16 \%$ respectively in the annual mean.

The importance of $\mathrm{BB}$ and anthropogenic emissions to $\mathrm{CCN}_{0.2 \%}$ increases significantly in the cloud and plume layers. Both $\mathrm{BB}$ and anthropogenic emissions are transported from the African continent. Due to the difference in altitude between the land and the ocean, the transport of these emissions is in the free troposphere above the cloud layer; therefore, BB and anthropogenic aerosol concentrations are decreasing with altitude and subsequently their contribution to $\mathrm{CCN}_{0.2 \%}$. In the cloud layer, $\mathrm{BB}$ contributes more to $\mathrm{CCN}_{0.2 \%}$ than anthropogenic emissions and is the largest source of $\mathrm{CCN}_{0.2 \%}$ in terms of emission sources. During BB season, $\mathrm{BB}$ contributes $43 \%$ of the $\mathrm{CCN}_{0.2 \%}$ in the cloud layer, even more than that from total nucleation, making $\mathrm{BB}$ the most significant source of $\mathrm{CCN}_{0.2 \%}$ overall (Fig. S3). The contribution of $\mathrm{BB}$ to $\mathrm{CCN}_{0.2 \%}$ further increases in the plume layer, with $\mathrm{BB}$ becoming the most dominant source of $\mathrm{CCN}_{0.2 \%}$ overall. The contribution of $\mathrm{BB}$ to $\mathrm{CCN}_{0.2 \%}$ in the plume layer is $64 \%$ on annual average, and increases to $76 \%$ during BB season. This result highlights the significant impact of BB aerosols

30 on $\mathrm{CCN}_{0.2 \%}$, especially during the $\mathrm{BB}$ season. However, as most of the $\mathrm{CCN}_{0.2 \%}$ contributed by the $\mathrm{BB}$ is distributed in the free troposphere, its effect on clouds is likely to be limited and similar to that of anthropogenic sources. 


\subsection{Cloud adjustments}

\subsubsection{Maximum supersaturation}

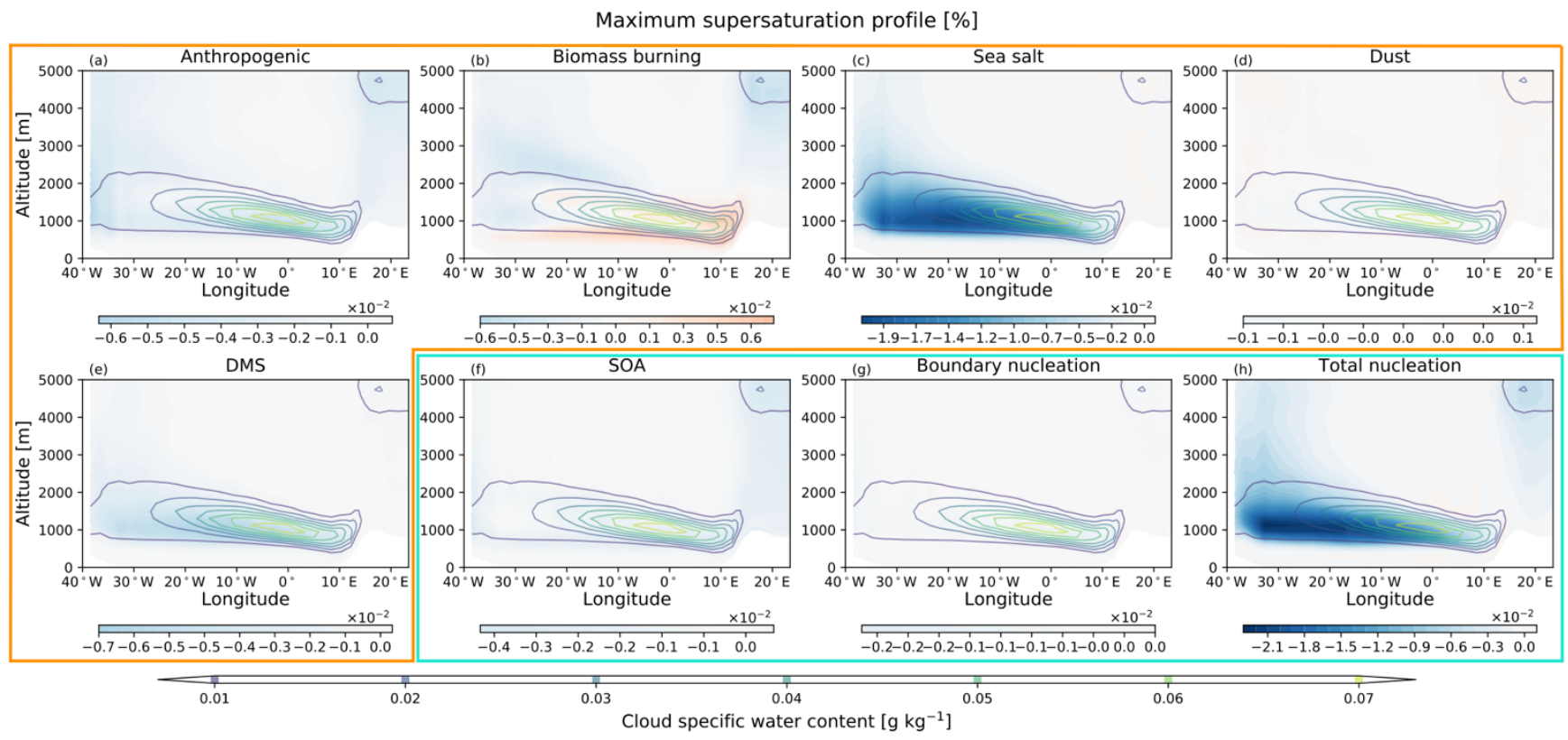

Figure 5. UKESM1 simulated annual mean vertical profiles of maximum supersaturation (\%) from different sources. Profiles

5 are averaged along the latitudes of the cloud box. The contributions of different sources to maximum supersaturation are listed in (a) to (h), where the contribution of emissions is shown in the yellow frame, and the contribution of atmospheric processes is shown in the light blue frame. The contour lines in each subplot are the cloud specific water content from the baseline simulation at the same temporal and spatial average. The same colourmap scale is used in each subplot to facilitate comparison, but the range differs in each plot, corresponding to the maximum and minimum of the maximum supersaturation.

As shown in Fig. 5, among the aerosols from various sources (emissions and atmospheric processes), BB aerosol is the only one that noticeably increases the maximum supersaturation. The increase in maximum supersaturation due to BB aerosol is more evident during the BB season, at approximately 0.028 \% (Fig. S4). By contrast, all other aerosols generally exhibit a decreasing effect on the maximum supersaturation. The increase in maximum supersaturation due to BB aerosols is caused by

15 their shortwave radiation absorption effect. As it can warm the air due to its absorption of shortwave radiation, BB aerosol can enhance the inversion layer over clouds, preserving water vapour within the boundary layer and increasing the maximum supersaturation, consistent with the finding in Che et al. (2021). Whereas for other types of aerosols, their effect on the maximum supersaturation is mainly through microphysical processes, i.e., acting as $\mathrm{CCN}$. These aerosols therefore provide condensation sinks for water vapour, resulting in a reduction of the maximum supersaturation. Thus, as the largest contributor 
to $\mathrm{CCN}_{0.2 \%}$ in the marine boundary layer, total nucleation has the strongest effect on reducing maximum supersaturation among others. The decrease in maximum supersaturation due to sea salt is also apparent, second only to the effect of total nucleation. However, the annual mean $\mathrm{CCN}_{0.2 \%}$ number concentration contributed by sea salt is low in the marine boundary layer, only accounting for one-sixth of that from total nucleation. This is because despite the low number concentrations, sea salt particle has a large diameter and therefore provides a larger surface to allow more water vapour to condense.

\subsubsection{Cloud droplet number concentration}

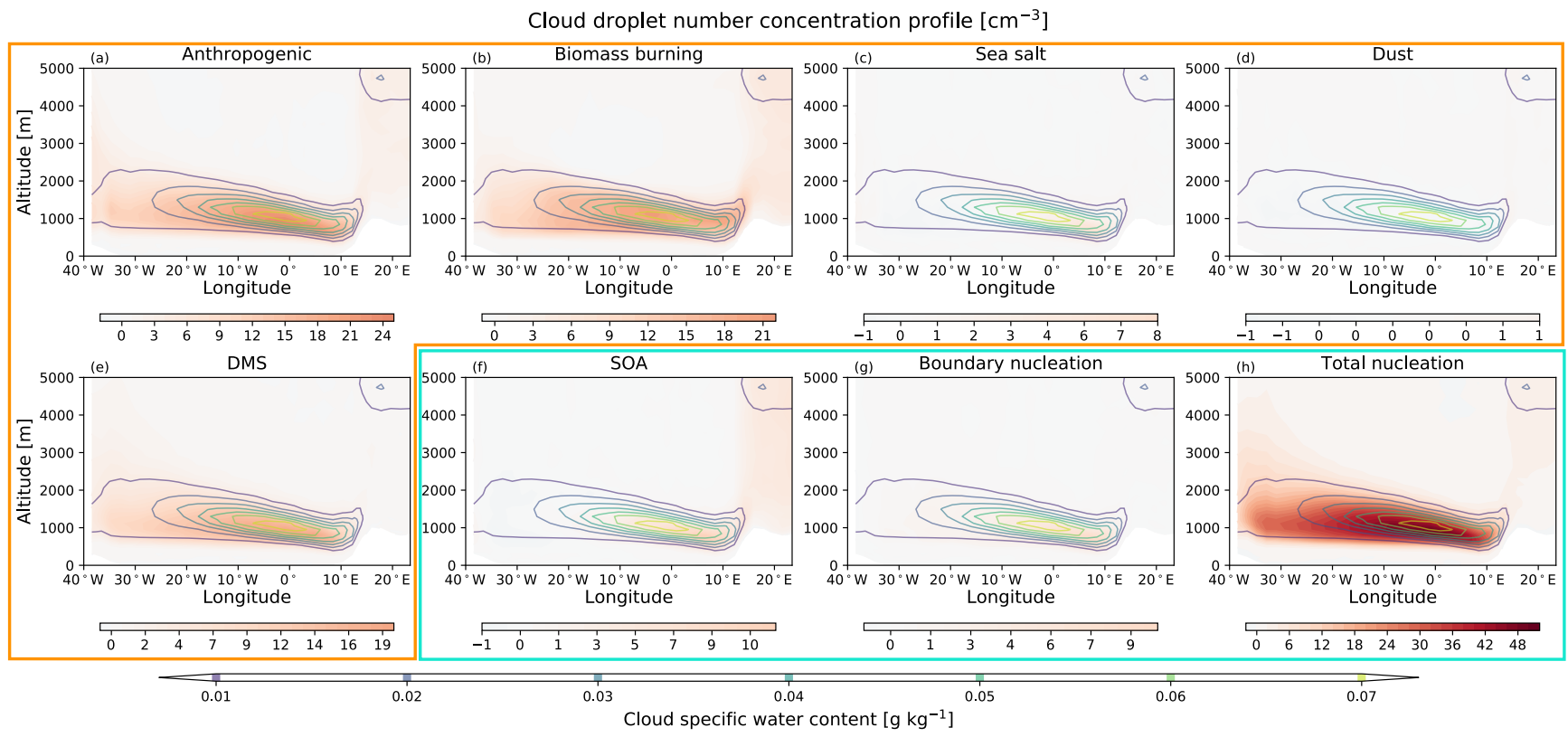

Figure 6. UKESM1 simulated annual mean vertical profiles of cloud droplet number concentration (CDCN) from different sources. Profiles are averaged along the latitudes of the cloud box. The contributions of different sources to CDCN are listed in (a) to (h), where the contribution of emissions is shown in the yellow frame, and the contribution of atmospheric processes is shown in the light blue frame. The contour lines in each subplot are the cloud specific water content from the baseline simulation at the same temporal and spatial average. The same colourmap scale is used in each subplot to facilitate comparison, but the range differs in each plot, corresponding to the maximum and minimum of the CDNC.

15 The annual means of cloud droplet number concentration (CDNC) from different sources are illustrated in figure 6. As can be seen from the figure, in general, the dominant source of $\mathrm{CDNC}$ is total nucleation, consistent with the source attribution of $\mathrm{CCN}_{0.2 \%}$ within the marine boundary layer. Even during the BB season, the concentration of CDNC contributed by total nucleation is similar to that contributed by BB (Fig. S5), indicating that total nucleation remains the most significant source of CDNC through the years. In terms of emission sources, anthropogenic emissions make the highest contribution to the annual 
mean CDNC, slightly higher than the contribution of BB. This finding is also consistent with the result that anthropogenic contribute the highest proportion of $\mathrm{CCN}_{0.2 \%}$ of all emissions in the marine boundary layer. $\mathrm{BB}$ contributes the second-largest annual mean of CDNC from all emissions, closely followed by the contribution from DMS, which is consistent with their contribution to $\mathrm{CCN}_{0.2 \%}$ within the marine boundary layer. However, during the BB season, the importance of BB to CDNC increases significantly, contributing about the same amount of CDNC as total nucleation and almost twice as much as the anthropogenic emission (Fig. S5). The contribution of BB to CDNC during the BB season is higher than its contribution to $\mathrm{CCN}_{0.2 \%}$ within the boundary layer. This inconsistency is mainly due to the different contribution mechanisms of BB aerosols to $\mathrm{CDNC}$ compared to other aerosols. For BB aerosols, they not only provide $\mathrm{CCN}$ to increase $\mathrm{CDNC}$, but also increase CDNC by influencing the vertical distribution of temperature through their shortwave radiation absorption ability, which in turn increases the maximum supersaturation in clouds (Che et al., 2021). This is also evidenced by Fig. 5. As a result, BB becomes the most important emission source of CDNC during the BB season.

\subsubsection{Liquid water path}

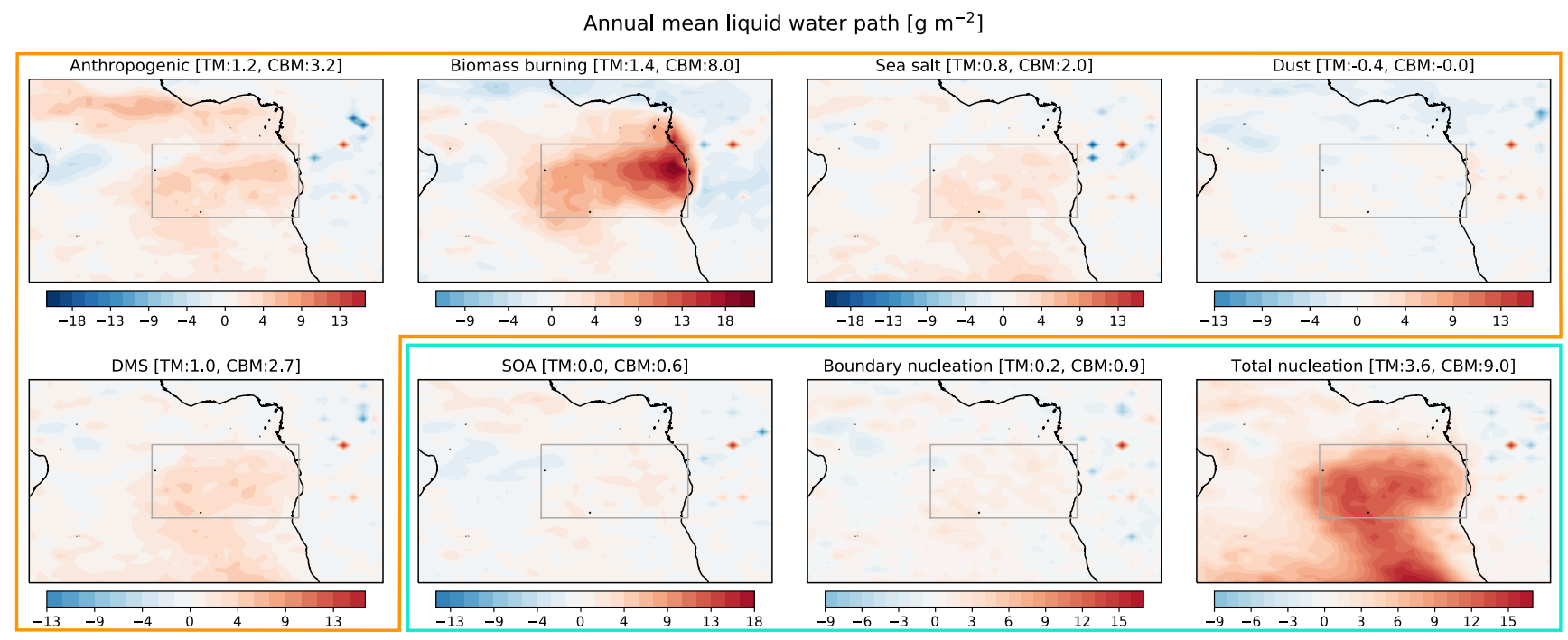

Figure 7. UKESM1 simulated annual mean liquid water path (LWP) from different sources. The contributions of different sources to LWP are listed in (a) to (h), where the contribution of emissions is shown in the yellow frame, and the contribution of atmospheric processes is shown in the light blue frame. The domain in each subplot ranges from $30^{\circ} \mathrm{S}$ to $10^{\circ} \mathrm{N}$, and from $40^{\circ} \mathrm{W}$ to $30^{\circ} \mathrm{E}$. The $\mathrm{TM}$ is the total mean of the domain, and the CBM is the mean of the cloud box (the grey box on the map). The same colourmap scale is used in each subplot to facilitate comparison, but the range differs for each plot, corresponding to the maximum and minimum of the LWP. 
This section examines cloud adjustments due to different sources of aerosols, with a focus on LWP. From figure 7, LWP corresponds well with the CDNC in general for different sources, which suggests that the increase in LWP is mainly due to the suppression of precipitation caused by the increase in CDNC. For sources having an apparent increase of CDNC, they also exhibit an increase of the LWP. However, the ratio of the increased LWP to increased CDNC is different for those sources due

5 to different aerosol properties. For the BB source, although the increased CDNC has a similar concentration to that from anthropogenic emissions and is around half of that from total nucleation, the amount of LWP increased by BB in the cloud box region is slightly lower than that increased by total nucleation, and is nearly three times of that from the anthropogenic sources. This can be attributed to the radiative effect of BB aerosol, strengthening existing temperature capping inversion and reducing entrainment if sub-saturated air from above (Che et al., 2021; Deaconu et al., 2019; Sakaeda et al., 2011; Wilcox,

10 2010, 2012), thus increasing LWP. Sea salt shows a comparable (slightly lower) increase in LWP to that of anthropogenic and DMS sources in the cloud region, although its contribution to CDNC is much lower than that of anthropogenic and DMS emissions. This is probably due to the high hygroscopicity of sea salt aerosols, which allows them to uptake a large amount of water vapour above certain relative humidity and retain it in the form of liquid in the particles. Other sources such as dust, SOA, and boundary layer nucleation only contribute a small amount of CDNC; therefore, the corresponding LWP increased

15 by those sources are also limited.

During the BB season, BB significantly increases the LWP within the cloud box region $\left(21.7 \mathrm{~g} / \mathrm{m}^{2}\right)$ and has the greatest impact on the LWP of all sources (figure S6). The amount of enhanced LWP by BB is two times to that by total nucleation in the cloud box region, even with the similar amount of CDNC contributed by those two sources during the BB season. The higher

20 LWP caused by BB reflects the critical role of the radiative effect of BB aerosol in affecting cloud properties, and is consistent with our previous finding (Che et al., 2021). 


\subsection{Radiative effects}

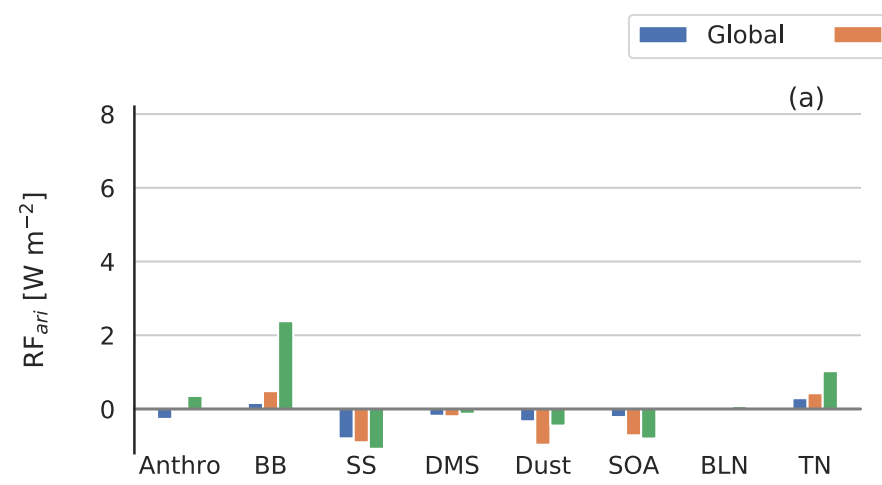

\section{SEA region}

Cloud box

(a)
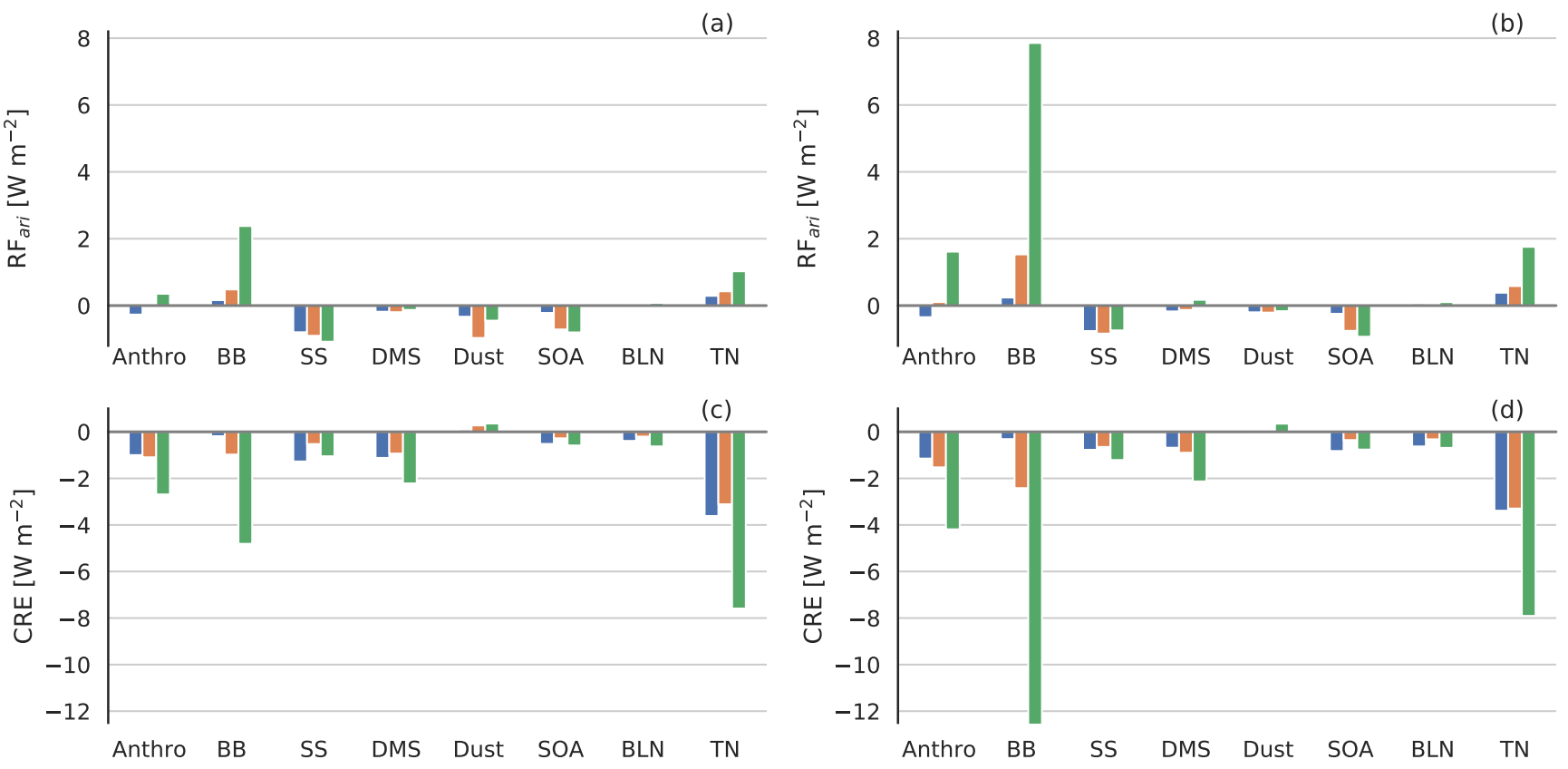

Figure 8. UKESM1 simulated radiative forcing from aerosol-radiation interaction ( $R F_{\text {ari }}$ ) and cloud radiative effect (CRE) for different sources. (a) and (b) are the annual mean and BB season mean of $\mathrm{RF}_{\text {ari, }}$, (c) and (d) are the annual mean and BB season mean of CRE. Antro, BB, SS, DMS, Dust, SOA, BLN, and TN represent sources of anthropogenic, BB, sea-salt, DMS, dust, SOA, boundary layer nucleation, and total nucleation, respectively. Blue, orange, and green colours represent the mean values averaged in the global, investigated SEA area, and cloud box region, respectively.

The radiative effects of different sources are investigated in this section. The radiative forcing from aerosol-radiation interactions $\left(\mathrm{RF}_{\mathrm{ari}}\right)$ and the cloud radiative effect $(\mathrm{CRE})$ from aerosol-cloud interactions are calculated using the method of Ghan (2013). CRE includes rapid adjustments from aerosol-radiation interactions (known as aerosol semi-direct effect), and the effective radiative forcing from aerosol-cloud interactions $\left(E R F_{a c i}\right)$. As the aerosol semi-direct effect can impact the temperature profile and further influence the cloud droplet size, number concentration, and cloud fraction, it is difficult to separate and reasonable to include it in the CRE. 
From figure 8, most aerosols exert a negative $\mathrm{RF}_{\text {ari }}$ except for those from $\mathrm{BB}$, anthropogenic, and total nucleation, especially in the cloud box region. As the sign of the $\mathrm{RF}_{\text {ari }}$ depends on the relative brightness of the underlying surface and particles, $\mathrm{RF}_{\text {ari }}$ of anthropogenic, BB, and total nucleation are positive in the cloud box region, as these aerosols are generally located above the cloud layer. This is more obvious for the BB season, during which the stratocumulus fraction and emissions from

5 anthropogenic and BB increase coincidentally in the cloud box region. However, at the regional SEA and global scales, only $\mathrm{BB}$ and total nucleation exhibit a warming $\mathrm{RF}_{\text {ari. }}$ This is because $\mathrm{BB}$ aerosols could absorb shortwave radiation and warm up the lower troposphere, while total nucleation produces a large number of small particles which can aggregate on the surface of the BC, thus increasing BC absorption through the coating. Sea salt exhibits the most notable cooling effect, and its RF ari shows little difference among global, the SEA, and the cloud box region. Although the aerosol concentration from sea salt is relatively low, the larger size of its particle makes sea salt the most crucial source of aerosol radiative cooling.

Most aerosol sources show a negative effect from global to cloud box area for the cloud radiative effect. Total nucleation dominates the annual negative $\mathrm{CRE}$, while during $\mathrm{BB}$ season, the most important source exerting negative CRE, especially on the cloud box region, is BB. This is consistent with the changes of LWP, as BB has brought a larger increase of LWP during

15 BB season than total nucleation. DMS shows negligible $\mathrm{RF}_{\text {ari }}$ but comparable CRE to that of anthropogenic sources, consistent with the finding that it contributes a similar amount to LWP with the anthropogenic source. Combining RFari and CRE, the effective radiative effect for each source is negative. The source showing the greatest total cooling is the total nucleation, though its $\mathrm{RF}_{\text {ari }}$ is warming, confirming the critical role of binary nucleation for the low-level background cloud properties and the global radiation balance.

\section{Discussion and conclusion}

In this paper, we use the United Kingdom Earth System Model (UKESM1) to attribute CCN and subsequent cloud property changes and radiative effects in the South-East Atlantic to different sources. The model has been evaluated with measurements from and CLARIFY and ORACLES flights data. This framework guides our understanding of the effect of different aerosol sources (emissions and atmospheric processes) on marine stratocumulus clouds and radiation in the SEA.

From the results, overall, total nucleation (binary nucleation) is the most important source of $\mathrm{CCN}_{0.2 \%}$ in the marine boundary layer and cloud layer, both in terms of the annual and the BB seasonal means. This result highlights the importance of the upper troposphere nucleation and subsequent subsidence, as well as binary nucleation within the boundary layer, to aerosol number concentrations. However, organic-mediated boundary layer nucleation contributes a much lower concentration of $30 \mathrm{CCN}_{0.2 \%}$, suggesting that it is not the main mechanism of $\mathrm{CCN}$ in the SEA region. In terms of emissions, anthropogenic is the largest source of $\mathrm{CCN}_{0.2 \%}$ in the marine boundary layer, contributing an average of $26 \%$ and $21 \%$ of $\mathrm{CCN}_{0.2 \%}$ in the annual 
and $\mathrm{BB}$ seasons, respectively. The contribution of $\mathrm{BB}$ to $\mathrm{CCN}_{0.2 \%}$ in the marine boundary layer closely follows that of anthropogenic sources, at an average of $17 \%$ and $19 \%$ in the annual and BB period, respectively. Anthropogenic emissions contribute more $\mathrm{CCN}_{0.2 \%}$ than $\mathrm{BB}$ in the marine boundary layer, even during the $\mathrm{BB}$ season, which may be attributed to $\mathrm{SO}_{2}$ emitted by the anthropogenic sources, as it can form aerosols through nucleation and thus provides more CCN. However, the importance of $\mathrm{BB}$ emissions to $\mathrm{CCN}_{0.2 \%}$ increases significantly in the cloud and plume layers. $\mathrm{BB}$ contributes $64 \%$ of the annual average $\mathrm{CCN}_{0.2 \%}$ in the plume layer, making it the most significant contributor of $\mathrm{CCN}_{0.2 \%}$. This result highlights the significant impact of $\mathrm{BB}$ aerosols on $\mathrm{CCN}_{0.2 \%}$, particularly in the region above the boundary layer. However, as most of the $\mathrm{CCN}_{0.2 \%}$ contributed by the $\mathrm{BB}$ is distributed in the free troposphere, its effect on clouds may still be limited by cloud-top entrainment. The contribution of aerosols from different sources to CDNC is consistent with their contribution to $\mathrm{CCN}_{0.2 \%}$

10 within the marine boundary layer in the cloud box region, highlighting the important role of boundary layer aerosols to clouds. Regardless of the annual or BB seasonal averages, total nucleation is the most dominant source of CDNC in general. In terms of emissions, anthropogenic sources are also the largest contributors to the annual average of CDNC, followed by BB. During the $\mathrm{BB}$ season, the contribution of $\mathrm{BB}$ to $\mathrm{CDNC}$ increases significantly (comparable to that of total nucleation to the $\mathrm{CDNC}$ ), and is much higher than the contribution of anthropogenic sources to CDNC. This is mainly because BB aerosol, in addition

15 to acting as $\mathrm{CCN}$ like anthropogenic aerosol, also can increase the maximum supersaturation through the radiative effect of its shortwave absorption, thus additionally increasing the CDNC.

LWP generally corresponds well with the source attributed CDNC; however, the ratio of increased LWP to CDNC is different. With only half of the increased CDNC due to total nucleation, BB increases LWP by a similar amount as total nucleation. The

20 high ratio of LWP enhancement by BB emissions highlights the key role of the absorption of BB aerosol, enhancing the existing temperature inversion and reducing the entrainment of sub-saturated air. Sea salt also increases a more significant amount of LWP compared to CDNC, which may be due to the high hygroscopicity of sea salt particles. During the BB season, $\mathrm{BB}$ is the most important aerosol source increasing the LWP. Even though both sources contribute similar amounts of CDNC, the LWP increase in the BB is twice as large as the total nuclei in the cloud box region, indicating the key role of the BB aerosol radiation effect in affecting cloud properties. Anthropogenic emissions, BB, and total nucleation exert a positive warming $\mathrm{RF}_{\text {ari }}$ in the cloud box region, as aerosols from those sources are mainly located above the clouds. Only aerosols from $\mathrm{BB}$ and total nucleation exert a positive $\mathrm{RF}_{\text {ari }}$ in both the $\mathrm{SEA}$ and global, which is because $\mathrm{BB}$ aerosol could absorb shortwave radiation and warm the lower troposphere, while those small particles from total nucleation can aggregate on the surface of $\mathrm{BC}$, thus increasing absorption through coating. Sea salt shows the most notable negative $\mathrm{RF}_{\text {ari, }}$ although the aerosol

30 concentration from sea salt is relatively low. For the cloud radiative effect, aerosol from all sources generally exhibits negative effects. Total nucleation dominates the annual-mean CRE perturbation, while during the BB season, BB dominates, consistent with the change of LWP. Combining $\mathrm{RF}_{\text {ari }}$ and $\mathrm{CRE}$, the effective radiative effect for each source is negative. The aerosol source showing the greatest total negative effect is the total nucleation, indicating the critical role of nucleation in modulating the background lower cloud properties and global radiation balance. 
In our previous model evaluations, although the model is generally able to well simulate the horizontal and vertical distribution of aerosols in the SEA, aerosols are slightly underestimated at higher altitudes and overestimated west of $5{ }^{\circ} \mathrm{W}(\mathrm{Che}$ et al., 2021). The latter is also confirmed by studies with the same model (though with different configurations), which also shown

5 an overestimation of aerosol concentrations in the western part of SEA (Gordon et al., 2020; Ranjithkumar et al., 2021). These model biases introduce some uncertainties into our results, particularly with respect to the effects of $\mathrm{BB}$ aerosols on $\mathrm{CCN}$ and clouds. In addition, Doherty et al. (2022) showed that cloud cover is biased high in this region, at least for the 2017 biomass burning season, which could also lead to an overestimation of CRE. As a result, our results are subject to a certain level of model uncertainties.

\section{Data availability}

The original model simulation data is available from JASMIN facility upon request.

\section{Author contributions}

PS and HC developed the concepts and ideas for the direction of the paper. HC and HG set up the model. HC carried out and

15 analysed the model simulation. DWP and HC performed the model validation, LD, DWP, HG, HC and PS contributed to the analysis of the results. HC wrote the paper with input and comments from all other authors.

\section{Competing interests}

The authors declare that they have no conflict of interest.

\section{Special issue statement}

20 This article is part of the special issue "New observations and related modelling studies of the aerosol- cloud-climate system in the Southeast Atlantic and southern Africa regions (ACP/AMT inter-journal SI)". It is not associated with a conference.

\section{Acknowledgements}

This research has been funded by the NERC CLARIFY project NE/L01355X/1. P.S. additionally acknowledges support from the NERC project NE/P013406/1 (A-CURE), the European Research Council (ERC) project constRaining the EffeCts of 
Aerosols on Precipitation (RECAP) and the H2020 project FORCeS under the European Union's Horizon 2020 research and innovation program with grant agreements 724602 and 821205, respectively. We sincerely acknowledge all CLARIFY and ORACLES science teams for data support. We acknowledge the use of the Monsoon2 system, a collaborative facility supplied under the Joint Weather and Climate Research Programme, a strategic partnership between the UK Met Office and the Natural

5 Environment Research Council (NERC). We also used the JASMIN facility (http://www.jasmin.ac.uk/) via the Centre for Environmental Data Analysis, funded by NERC and the UK Space Agency and delivered by the Science and Technology Facilities Council.

\section{References}

Ackerman, A. S., Kirkpatrick, M. P., Stevens, D. E., and Toon, O. B.: The impact of humidity above stratiform clouds on indirect aerosol climate forcing, Nature, 432, 1014, https://doi.org/10.1038/nature03174, 2004.

Albrecht, B. A.: Aerosols, cloud microphysics, and fractional cloudiness, Science, 245, 1227-1230, https://doi.org/10.1126/science.245.4923.1227, 1989.

Andreae, M. O.: Ocean-atmosphere interactions in the global biogeochemical sulfur cycle, Mar. Chem., 30, 1-29, https://doi.org/10.1016/0304-4203(90)90059-L, 1990.

15 Bègue, N., Tulet, P., Pelon, J., Aouizerats, B., Berger, A., and Schwarzenboeck, A.: Aerosol processing and CCN formation of an intense Saharan dust plume during the EUCAARI 2008 campaign, Atmospheric Chem. Phys., 15, 3497-3516, https://doi.org/10.5194/acp-15-3497-2015, 2015.

Berner, A. H., Bretherton, C. S., and Wood, R.: Large eddy simulation of ship tracks in the collapsed marine boundary layer: a case study from the Monterey area ship track experiment, Atmospheric Chem. Phys., 15, 5851-5871, https://doi.org/10.5194/acp-15-5851-2015, 2015.

Bhattachan, A., D’Odorico, P., Baddock, M. C., Zobeck, T. M., Okin, G. S., and Cassar, N.: The Southern Kalahari: a potential new dust source in the Southern Hemisphere?, Environ. Res. Lett., 7, 024001, https://doi.org/10.1088/1748-9326/7/2/024001, 2012.

Boucher, O., Randall, D., Artaxo, P., Bretherton, C., Feingold, G., Forster, P., Kerminen, V.-M., Kondo, Y., Liao, H.,

25 Lohmann, U., Rasch, P., Satheesh, S. K., Sherwood, S., Stevens, B., and Zhang, X. Y.: Clouds and aerosols, in: Climate Change 2013: The Physical Science Basis. Contribution of Working Group I to the Fifth Assessment Report of the Intergovernmental Panel on Climate Change, edited by: Stocker, T. F., Qin, D., Plattner, G.-K., Tignor, M., Allen, S. K., Doschung, J., Nauels, A., Xia, Y., Bex, V., and Midgley, P. M., Cambridge University Press, Cambridge, UK, 571-657, https://doi.org/10.1017/CBO9781107415324.016, 2013.

30 Charlson, R. J., Lovelock, J. E., Andreae, M. O., and Warren, S. G.: Oceanic phytoplankton, atmospheric sulphur, cloud albedo and climate, Nature, 326, 655-661, https://doi.org/10.1038/326655a0, 1987.

Che, H., Stier, P., Gordon, H., Watson-Parris, D., and Deaconu, L.: Cloud adjustments dominate the overall negative aerosol radiative effects of biomass burning aerosols in UKESM1 climate model simulations over the south-eastern Atlantic, Atmospheric Chem. Phys., 21, 17-33, https://doi.org/10.5194/acp-21-17-2021, 2021. 
Che, H. C., Zhang, X. Y., Zhang, L., Wang, Y. Q., Zhang, Y. M., Shen, X. J., Ma, Q. L., Sun, J. Y., and Zhong, J. T.: Prediction of size-resolved number concentration of cloud condensation nuclei and long-term measurements of their activation characteristics, Sci. Rep., 7, https://doi.org/10.1038/s41598-017-05998-3, 2017.

Clarke, A. D. and Kapustin, V. N.: A Pacific Aerosol Survey. Part I: A Decade of Data on Particle Production, Transport, 5 Evolution, and Mixing in the Troposphere, J. Atmospheric Sci., 59, 363-382, https://doi.org/10.1175/15200469(2002)059<0363:APASPI >2.0.CO;2, 2002.

Clarke, A. D., Freitag, S., Simpson, R. M. C., Hudson, J. G., Howell, S. G., Brekhovskikh, V. L., Campos, T., Kapustin, V. N., and Zhou, J.: Free troposphere as a major source of $\mathrm{CCN}$ for the equatorial pacific boundary layer: long-range transport and teleconnections, Atmospheric Chem. Phys., 13, 7511-7529, https://doi.org/10.5194/acp-13-7511-2013, 2013.

10 Deaconu, L. T., Ferlay, N., Waquet, F., Peers, F., Thieuleux, F., and Goloub, P.: Satellite inference of water vapor and aerosolabove-cloud combined effect on radiative budget and cloud top processes in the Southeast Atlantic Ocean, Atmospheric Chem. Phys. Discuss., 1-34, https://doi.org/10.5194/acp-2019-189, 2019.

Doherty, S. J., Saide, P. E., Zuidema, P., Shinozuka, Y., Ferrada, G. A., Gordon, H., Mallet, M., Meyer, K., Painemal, D., Howell, S. G., Freitag, S., Dobracki, A., Podolske, J. R., Burton, S. P., Ferrare, R. A., Howes, C., Nabat, P., Carmichael, G.

15 R., da Silva, A., Pistone, K., Chang, I., Gao, L., Wood, R., and Redemann, J.: Modeled and observed properties related to the direct aerosol radiative effect of biomass burning aerosol over the southeastern Atlantic, Atmospheric Chem. Phys., 22, 1-46, https://doi.org/10.5194/acp-22-1-2022, 2022.

Dusek, U., Frank, G. P., Hildebrandt, L., Curtius, J., Schneider, J., Walter, S., Chand, D., Drewnick, F., Hings, S., Jung, D., Borrmann, S., and Andreae, M. O.: Size matters more than chemistry for cloud-nucleating ability of aerosol particles, Science, 312, 1375-1378, https://doi.org/10.1126/science.1125261, 2006.

Engelhart, G. J., Hennigan, C. J., Miracolo, M. A., Robinson, A. L., and Pandis, S. N.: Cloud condensation nuclei activity of fresh primary and aged biomass burning aerosol, Atmospheric Chem. Phys., 12, 7285-7293, https://doi.org/10.5194/acp-127285-2012, 2012.

Eyring, V., Bony, S., Meehl, G. A., Senior, C. A., Stevens, B., Stouffer, R. J., and Taylor, K. E.: Overview of the Coupled 25 Model Intercomparison Project Phase 6 (CMIP6) experimental design and organization, Geosci. Model Dev., 9, 1937-1958, https://doi.org/10.5194/gmd-9-1937-2016, 2016.

Ghan, S. J.: Technical Note: Estimating aerosol effects on cloud radiative forcing, Atmos Chem Phys, 13, 9971-9974, https://doi.org/10.5194/acp-13-9971-2013, 2013.

Gibson, E. R., Gierlus, K. M., Hudson, P. K., and Grassian, V. H.: Generation of Internally Mixed Insoluble and Soluble 30 Aerosol Particles to Investigate the Impact of Atmospheric Aging and Heterogeneous Processing on the CCN Activity of Mineral Dust Aerosol, Aerosol Sci. Technol., 41, 914-924, https://doi.org/10.1080/02786820701557222, 2007.

Gidden, M. J., Riahi, K., Smith, S. J., Fujimori, S., Luderer, G., Kriegler, E., Vuuren, D. P. van, Berg, M. van den, Feng, L., Klein, D., Calvin, K., Doelman, J. C., Frank, S., Fricko, O., Harmsen, M., Hasegawa, T., Havlik, P., Hilaire, J., Hoesly, R., Horing, J., Popp, A., Stehfest, E., and Takahashi, K.: Global emissions pathways under different socioeconomic scenarios for 35 use in CMIP6: a dataset of harmonized emissions trajectories through the end of the century, Geosci. Model Dev., 12, 14431475, https://doi.org/10.5194/gmd-12-1443-2019, 2019.

Gordon, H., Field, P. R., Abel, S. J., Dalvi, M., Grosvenor, D. P., Hill, A. A., Johnson, B. T., Miltenberger, A. K., Yoshioka, M., and Carslaw, K. S.: Large simulated radiative effects of smoke in the south-east Atlantic, Atmospheric Chem. Phys., 18, 15261-15289, https://doi.org/10.5194/acp-18-15261-2018, 2018. 
Gordon, H., Field, P. R., Abel, S. J., Barrett, P., Bower, K., Crawford, I., Cui, Z., Grosvenor, D. P., Hill, A. A., Taylor, J., Wilkinson, J., Wu, H., and Carslaw, K. S.: Development of aerosol activation in the double-moment Unified Model and evaluation with CLARIFY measurements, Atmospheric Chem. Phys., 20, 10997-11024, https://doi.org/10.5194/acp-2010997-2020, 2020.

5 Hahn, C. and Warren, S.: A Gridded Climatology of Clouds over Land (1971-1996) and Ocean (1954-2008) from Surface Observations Worldwide (NDP-026E)*, https://doi.org/10.3334/CDIAC/CLI.NDP026E, 2007.

Hatch, C. D., Gierlus, K. M., Schuttlefield, J. D., and Grassian, V. H.: Water adsorption and cloud condensation nuclei activity of calcite and calcite coated with model humic and fulvic acids, Atmos. Environ., 42, 5672-5684, https://doi.org/10.1016/j.atmosenv.2008.03.005, 2008.

10 Haywood, J. M., Abel, S. J., Barrett, P. A., Bellouin, N., Blyth, A., Bower, K. N., Brooks, M., Carslaw, K., Che, H., Coe, H., Cotterell, M. I., Crawford, I., Cui, Z., Davies, N., Dingley, B., Field, P., Formenti, P., Gordon, H., de Graaf, M., Herbert, R., Johnson, B., Jones, A. C., Langridge, J. M., Malavelle, F., Partridge, D. G., Peers, F., Redemann, J., Stier, P., Szpek, K., Taylor, J. W., Watson-Parris, D., Wood, R., Wu, H., and Zuidema, P.: The CLoud-Aerosol-Radiation Interaction and Forcing: Year 2017 (CLARIFY-2017) measurement campaign, Atmospheric Chem. Phys., 21, 1049-1084, https://doi.org/10.5194/acp15 21-1049-2021, 2021.

Hewitt, H. T., Copsey, D., Culverwell, I. D., Harris, C. M., Hill, R. S. R., Keen, A. B., McLaren, A. J., and Hunke, E. C.: Design and implementation of the infrastructure of HadGEM3: the next-generation Met Office climate modelling system, Geosci. Model Dev., 4, 223-253, https://doi.org/10.5194/gmd-4-223-2011, 2011.

Johnson, B. T., Shine, K. P., and Forster, P. M.: The semi-direct aerosol effect: Impact of absorbing aerosols on marine stratocumulus, Q. J. R. Meteorol. Soc., 130, 1407-1422, https://doi.org/10.1256/qj.03.61, 2004.

Johnson, B. T., Haywood, J. M., Langridge, J. M., Darbyshire, E., Morgan, W. T., Szpek, K., Brooke, J. K., Marenco, F., Coe, H., Artaxo, P., Longo, K. M., Mulcahy, J. P., Mann, G. W., Dalvi, M., and Bellouin, N.: Evaluation of biomass burning aerosols in the HadGEM3 climate model with observations from the SAMBBA field campaign, Atmospheric Chem. Phys., 16, 1465714685, https://doi.org/10.5194/acp-16-14657-2016, 2016.

25 Kerminen, V.-M., Paramonov, M., Anttila, T., Riipinen, I., Fountoukis, C., Korhonen, H., Asmi, E., Laakso, L., Lihavainen, H., Swietlicki, E., Svenningsson, B., Asmi, A., Pandis, S. N., Kulmala, M., and Petäjä, T.: Cloud condensation nuclei production associated with atmospheric nucleation: a synthesis based on existing literature and new results, Atmospheric Chem. Phys., 12, 12037-12059, https://doi.org/10.5194/acp-12-12037-2012, 2012.

Klein, S. A. and Hartmann, D. L.: The Seasonal Cycle of Low Stratiform Clouds, J. Clim., 6, 1587-1606, https://doi.org/10.1175/1520-0442(1993)006<1587:TSCOLS>2.0.CO;2, 1993.

Kuang, C., McMurry, P. H., and McCormick, A. V.: Determination of cloud condensation nuclei production from measured new particle formation events, Geophys. Res. Lett., 36, https://doi.org/10.1029/2009GL037584, 2009.

Kulmala, M. and Kerminen, V. M.: On the formation and growth of atmospheric nanoparticles, Atmospheric Res., 90, 132150, https://doi.org/10.1016/j.atmosres.2008.01.005, 2008.

35 Kulmala, M., Vehkamäki, H., Petäjä, T., Dal Maso, M., Lauri, A., Kerminen, V.-M., Birmili, W., and McMurry, P. H.: Formation and growth rates of ultrafine atmospheric particles: a review of observations, J. Aerosol Sci., 35, 143-176, https://doi.org/10.1016/j.jaerosci.2003.10.003, 2004. 
Lee, S.-H., Reeves, J. M., Wilson, J. C., Hunton, D. E., Viggiano, A. A., Miller, T. M., Ballenthin, J. O., and Lait, L. R.: Particle Formation by Ion Nucleation in the Upper Troposphere and Lower Stratosphere, Science, 301, 1886-1889, https://doi.org/10.1126/science.1087236, 2003.

Liousse, C., Assamoi, E., Criqui, P., Granier, C., and Rosset, R.: Explosive growth in African combustion emissions from

Lu, Z., Liu, X., Zhang, Z., Zhao, C., Meyer, K., Rajapakshe, C., Wu, C., Yang, Z., and Penner, J. E.: Biomass smoke from southern Africa can significantly enhance the brightness of stratocumulus over the southeastern Atlantic Ocean, Proc. Natl. Acad. Sci., 115, 2924-2929, https://doi.org/10.1073/pnas.1713703115, 2018.

Mallet, M., Solmon, F., Nabat, P., Elguindi, N., Waquet, F., Bouniol, D., Sayer, A. M., Meyer, K., Roehrig, R., Michou, M., 10 Zuidema, P., Flamant, C., Redemann, J., and Formenti, P.: Direct and semi-direct radiative forcing of biomass-burning aerosols over the southeast Atlantic (SEA) and its sensitivity to absorbing properties: a regional climate modeling study, Atmospheric Chem. Phys., 20, 13191-13216, https://doi.org/10.5194/acp-20-13191-2020, 2020.

Mann, G. W., Carslaw, K. S., Spracklen, D. V., Ridley, D. A., Manktelow, P. T., Chipperfield, M. P., Pickering, S. J., and Johnson, C. E.: Description and evaluation of GLOMAP-mode: a modal global aerosol microphysics model for the UKCA composition-climate model, Geosci Model Dev, 3, 519-551, https://doi.org/10.5194/gmd-3-519-2010, 2010.

Mentel, T. F., Wildt, J., Kiendler-Scharr, A., Kleist, E., Tillmann, R., Maso, M. D., Fisseha, R., Hohaus, T., Spahn, H., Uerlings, R., Wegener, R., Griffiths, P. T., Dinar, E., Rudich, Y., and Wahner, A.: Photochemical production of aerosols from real plant emissions, Atmospheric Chem. Phys., 9, 4387-4406, https://doi.org/10.5194/acp-9-4387-2009, 2009.

Merikanto, J., Spracklen, D. V., Mann, G. W., Pickering, S. J., and Carslaw, K. S.: Impact of nucleation on global CCN, Atmospheric Chem. Phys., 9, 8601-8616, https://doi.org/10.5194/acp-9-8601-2009, 2009.

Metzger, A., Verheggen, B., Dommen, J., Duplissy, J., Prevot, A. S. H., Weingartner, E., Riipinen, I., Kulmala, M., Spracklen, D. V., Carslaw, K. S., and Baltensperger, U.: Evidence for the role of organics in aerosol particle formation under atmospheric conditions, Proc. Natl. Acad. Sci., 107, 6646-6651, https://doi.org/10.1073/pnas.0911330107, 2010.

Mulcahy, J. P., Johnson, C., Jones, C. G., Povey, A. C., Scott, C. E., Sellar, A., Turnock, S. T., Woodhouse, M. T., Abraham, 25 N. L., Andrews, M. B., Bellouin, N., Browse, J., Carslaw, K. S., Dalvi, M., Folberth, G. A., Glover, M., Grosvenor, D., Hardacre, C., Hill, R., Johnson, B., Jones, A., Kipling, Z., Mann, G., Mollard, J., O’Connor, F. M., Palmieri, J., Reddington, C., Rumbold, S. T., Richardson, M., Schutgens, N. A. J., Stier, P., Stringer, M., Tang, Y., Walton, J., Woodward, S., and Yool, A.: Description and evaluation of aerosol in UKESM1 and HadGEM3-GC3.1 CMIP6 historical simulations, Submitted, 2020.

O’Connor, F. M., Johnson, C. E., Morgenstern, O., Abraham, N. L., Braesicke, P., Dalvi, M., Folberth, G. A., Sanderson, M.

30 G., Telford, P. J., Voulgarakis, A., Young, P. J., Zeng, G., Collins, W. J., and Pyle, J. A.: Evaluation of the new UKCA climatecomposition model - Part 2: The Troposphere, Geosci Model Dev, 7, 41-91, https://doi.org/10.5194/gmd-7-41-2014, 2014.

Petters, M. D. and Kreidenweis, S. M.: A single parameter representation of hygroscopic growth and cloud condensation nucleus activity, Atmospheric Chem. Phys., 7, 1961-1971, https://doi.org/10.5194/acp-7-1961-2007, 2007.

Pierce, J. R. and Adams, P. J.: Global evaluation of CCN formation by direct emission of sea salt and growth of ultrafine sea salt, J. Geophys. Res. Atmospheres, 111, https://doi.org/10.1029/2005JD006186, 2006.

Quinn, P. K., Coffman, D. J., Johnson, J. E., Upchurch, L. M., and Bates, T. S.: Small fraction of marine cloud condensation nuclei made up of sea spray aerosol, Nat. Geosci., 10, 674, https://doi.org/10.1038/ngeo3003, 2017. 
Ranjithkumar, A., Gordon, H., Williamson, C., Rollins, A., Pringle, K., Kupc, A., Abraham, N. L., Brock, C., and Carslaw, $\mathrm{K}$.: Constraints on global aerosol number concentration, $\mathrm{SO}_{2}$ and condensation sink in UKESM1 using ATom measurements, Atmospheric Chem. Phys., 21, 4979-5014, https://doi.org/10.5194/acp-21-4979-2021, 2021.

Redemann, J., Wood, R., Zuidema, P., Doherty, S. J., Luna, B., LeBlanc, S. E., Diamond, M. S., Shinozuka, Y., Chang, I. Y., 5 Ueyama, R., Pfister, L., Ryoo, J.-M., Dobracki, A. N., da Silva, A. M., Longo, K. M., Kacenelenbogen, M. S., Flynn, C. J., Pistone, K., Knox, N. M., Piketh, S. J., Haywood, J. M., Formenti, P., Mallet, M., Stier, P., Ackerman, A. S., Bauer, S. E., Fridlind, A. M., Carmichael, G. R., Saide, P. E., Ferrada, G. A., Howell, S. G., Freitag, S., Cairns, B., Holben, B. N., Knobelspiesse, K. D., Tanelli, S., L’Ecuyer, T. S., Dzambo, A. M., Sy, O. O., McFarquhar, G. M., Poellot, M. R., Gupta, S., O’Brien, J. R., Nenes, A., Kacarab, M., Wong, J. P. S., Small-Griswold, J. D., Thornhill, K. L., Noone, D., Podolske, J. R.,

10 Schmidt, K. S., Pilewskie, P., Chen, H., Cochrane, S. P., Sedlacek, A. J., Lang, T. J., Stith, E., Segal-Rozenhaimer, M., Ferrare, R. A., Burton, S. P., Hostetler, C. A., Diner, D. J., Seidel, F. C., Platnick, S. E., Myers, J. S., Meyer, K. G., Spangenberg, D. A., Maring, H., and Gao, L.: An overview of the ORACLES (ObseRvations of Aerosols above CLouds and their intEractionS) project: aerosol-cloud-radiation interactions in the southeast Atlantic basin, Atmospheric Chem. Phys., 21, 1507-1563, https://doi.org/10.5194/acp-21-1507-2021, 2021.

15 Reynolds, R. W., Smith, T. M., Liu, C., Chelton, D. B., Casey, K. S., and Schlax, M. G.: Daily High-Resolution-Blended Analyses for Sea Surface Temperature, J. Clim., 20, 5473-5496, https://doi.org/10.1175/2007JCLI1824.1, 2007.

Roberts, G., Wooster, M. J., and Lagoudakis, E.: Annual and diurnal african biomass burning temporal dynamics, Biogeosciences, 6, 849-866, https://doi.org/10.5194/bg-6-849-2009, 2009.

Rose, D., Gunthe, S. S., Su, H., Garland, R. M., Yang, H., Berghof, M., Cheng, Y. F., Wehner, B., Achtert, P., Nowak, A.,

20 Wiedensohler, A., Takegawa, N., Kondo, Y., Hu, M., Zhang, Y., Andreae, M. O., and Pöschl, U.: Cloud condensation nuclei in polluted air and biomass burning smoke near the mega-city Guangzhou, China -Part 2: Size-resolved aerosol chemical composition, diurnal cycles, and externally mixed weakly CCN-active soot particles, Atmospheric Chem. Phys., 11, 28172836, https://doi.org/10.5194/acp-11-2817-2011, 2011.

Sakaeda, N., Wood, R., and Rasch, P. J.: Direct and semidirect aerosol effects of southern African biomass burning aerosol, J.

Geophys. Res. Atmospheres, 116, https://doi.org/10.1029/2010JD015540, 2011.

Sanchez, K. J., Chen, C.-L., Russell, L. M., Betha, R., Liu, J., Price, D. J., Massoli, P., Ziemba, L. D., Crosbie, E. C., Moore, R. H., Müller, M., Schiller, S. A., Wisthaler, A., Lee, A. K. Y., Quinn, P. K., Bates, T. S., Porter, J., Bell, T. G., Saltzman, E. S., Vaillancourt, R. D., and Behrenfeld, M. J.: Substantial Seasonal Contribution of Observed Biogenic Sulfate Particles to Cloud Condensation Nuclei, Sci. Rep., 8, 1-14, https://doi.org/10.1038/s41598-018-21590-9, 2018.

30 Schenkels, M.: Aerosol Optical Depth and Cloud Parameters from Ascension Island retrieved with a UV-depolarisation Lidar; An outlook on the validation, Master thesis, Utrecht University, 2018.

Schmale, J., Henning, S., Decesari, S., Henzing, B., Keskinen, H., Sellegri, K., Ovadnevaite, J., Pöhlker, M. L., Brito, J., Bougiatioti, A., Kristensson, A., Kalivitis, N., Stavroulas, I., Carbone, S., Jefferson, A., Park, M., Schlag, P., Iwamoto, Y., Aalto, P., Äijälä, M., Bukowiecki, N., Ehn, M., Frank, G., Fröhlich, R., Frumau, A., Herrmann, E., Herrmann, H., Holzinger,

35 R., Kos, G., Kulmala, M., Mihalopoulos, N., Nenes, A., O’Dowd, C., Petäjä, T., Picard, D., Pöhlker, C., Pöschl, U., Poulain, L., Prévôt, A. S. H., Swietlicki, E., Andreae, M. O., Artaxo, P., Wiedensohler, A., Ogren, J., Matsuki, A., Yum, S. S., Stratmann, F., Baltensperger, U., and Gysel, M.: Long-term cloud condensation nuclei number concentration, particle number size distribution and chemical composition measurements at regionally representative observatories, Atmospheric Chem. Phys., 18, 2853-2881, https://doi.org/10.5194/acp-18-2853-2018, 2018.

40 Seinfeld, J. H. and Pandis, S. N.: Atmospheric chemistry and physics: from air pollution to climate change, Wiley, 1364 pp., 1998. 
Sellar, A. A., Jones, C. G., Mulcahy, J. P., Tang, Y., Yool, A., Wiltshire, A., O’Connor, F. M., Stringer, M., Hill, R., Palmieri, J., Woodward, S., Mora, L. de, Kuhlbrodt, T., Rumbold, S. T., Kelley, D. I., Ellis, R., Johnson, C. E., Walton, J., Abraham, N. L., Andrews, M. B., Andrews, T., Archibald, A. T., Berthou, S., Burke, E., Blockley, E., Carslaw, K., Dalvi, M., Edwards, J., Folberth, G. A., Gedney, N., Griffiths, P. T., Harper, A. B., Hendry, M. A., Hewitt, A. J., Johnson, B., Jones, A., Jones, C. D., 5 Keeble, J., Liddicoat, S., Morgenstern, O., Parker, R. J., Predoi, V., Robertson, E., Siahaan, A., Smith, R. S., Swaminathan, R., Woodhouse, M. T., Zeng, G., and Zerroukat, M.: UKESM1: Description and Evaluation of the U.K. Earth System Model, J. Adv. Model. Earth Syst., 11, 4513-4558, https://doi.org/10.1029/2019MS001739, 2019.

Spracklen, D. V., Carslaw, K. S., Kulmala, M., Kerminen, V.-M., Mann, G. W., and Sihto, S.-L.: The contribution of boundary layer nucleation events to total particle concentrations on regional and global scales, Atmospheric Chem. Phys., 6, 5631-5648, https://doi.org/10.5194/acp-6-5631-2006, 2006.

Stephens, G. and Slingo, T.: An air-conditioned greenhouse, Nature, 358, 369-370, https://doi.org/10.1038/358369a0, 1992.

Swap, R., Garstang, M., Macko, S. A., Tyson, P. D., Maenhaut, W., Artaxo, P., Kållberg, P., and Talbot, R.: The long-range transport of southern African aerosols to the tropical South Atlantic, J. Geophys. Res. Atmospheres, 101, 23777-23791, https://doi.org/10.1029/95JD01049, 1996.

15 Telford, P. J., Braesicke, P., Morgenstern, O., and Pyle, J. A.: Technical Note: Description and assessment of a nudged version of the new dynamics Unified Model, Atmos Chem Phys, 8, 1701-1712, https://doi.org/10.5194/acp-8-1701-2008, 2008.

Textor, C., Schulz, M., Guibert, S., Kinne, S., Balkanski, Y., Bauer, S., Berntsen, T., Berglen, T., Boucher, O., Chin, M., Dentener, F., Diehl, T., Easter, R., Feichter, H., Fillmore, D., Ghan, S., Ginoux, P., Gong, S., Grini, A., Hendricks, J., Horowitz, L., Huang, P., Isaksen, I., Iversen, I., Kloster, S., Koch, D., Kirkevåg, A., Kristjansson, J. E., Krol, M., Lauer, A., Lamarque,

20 J. F., Liu, X., Montanaro, V., Myhre, G., Penner, J., Pitari, G., Reddy, S., Seland, Ø., Stier, P., Takemura, T., and Tie, X.: Analysis and quantification of the diversities of aerosol life cycles within AeroCom, Atmospheric Chem. Phys., 6, 1777-1813, https://doi.org/10.5194/acp-6-1777-2006, 2006.

Thomas, M. A., Suntharalingam, P., Pozzoli, L., Rast, S., Devasthale, A., Kloster, S., Feichter, J., and Lenton, T. M.: Quantification of DMS aerosol-cloud-climate interactions using the ECHAM5-HAMMOZ model in a current climate scenario,

25 Atmospheric Chem. Phys., 10, 7425-7438, https://doi.org/10.5194/acp-10-7425-2010, 2010.

Tsigaridis, K., Koch, D., and Menon, S.: Uncertainties and importance of sea spray composition on aerosol direct and indirect effects, J. Geophys. Res. Atmospheres, 118, 220-235, https://doi.org/10.1029/2012JD018165, 2013.

Twomey, S.: Pollution and the planetary albedo, Atmos Env., 8, 1251-1256, 1974.

Vehkamäki, H., Kulmala, M., Napari, I., Lehtinen, K. E. J., Timmreck, C., Noppel, M., and Laaksonen, A.: An improved 30 parameterization for sulfuric acid-water nucleation rates for tropospheric and stratospheric conditions, J. Geophys. Res. Atmospheres, 107, AAC 3-1-AAC 3-10, https://doi.org/10.1029/2002JD002184, 2002.

van der Werf, G. R., Randerson, J. T., Giglio, L., Collatz, G. J., Mu, M., Kasibhatla, P. S., Morton, D. C., DeFries, R. S., Jin, Y., and Leeuwen, T. T. van: Global fire emissions and the contribution of deforestation, savanna, forest, agricultural, and peat fires (1997-2009), Atmospheric Chem. Phys., 10, 11707-11735, https://doi.org/10.5194/acp-10-11707-2010, 2010.

35 Westervelt, D. M., Pierce, J. R., Riipinen, I., Trivitayanurak, W., Hamed, A., Kulmala, M., Laaksonen, A., Decesari, S., and Adams, P. J.: Formation and growth of nucleated particles into cloud condensation nuclei: model-measurement comparison, Atmospheric Chem. Phys., 13, 7645-7663, https://doi.org/10.5194/acp-13-7645-2013, 2013. 
Wilcox, E. M.: Stratocumulus cloud thickening beneath layers of absorbing smoke aerosol, Atmospheric Chem. Phys., 10, 11769-11777, https://doi.org/10.5194/acp-10-11769-2010, 2010.

Wilcox, E. M.: Direct and semi-direct radiative forcing of smoke aerosols over clouds, Atmospheric Chem. Phys., 12, 139149, https://doi.org/10.5194/acp-12-139-2012, 2012.

5 Williamson, C. J., Kupc, A., Axisa, D., Bilsback, K. R., Bui, T., Campuzano-Jost, P., Dollner, M., Froyd, K. D., Hodshire, A. L., Jimenez, J. L., Kodros, J. K., Luo, G., Murphy, D. M., Nault, B. A., Ray, E. A., Weinzierl, B., Wilson, J. C., Yu, F., Yu, P., Pierce, J. R., and Brock, C. A.: A large source of cloud condensation nuclei from new particle formation in the tropics, Nature, 574, 399-403, https://doi.org/10.1038/s41586-019-1638-9, 2019.

Wood, R.: Stratocumulus Clouds, Mon. Weather Rev., 140, 2373-2423, https://doi.org/10.1175/MWR-D-11-00121.1, 2012.

10 Woodward, S.: Modeling the atmospheric life cycle and radiative impact of mineral dust in the Hadley Centre climate model, J. Geophys. Res. Atmospheres, 106, 18155-18166, https://doi.org/10.1029/2000JD900795, 2001.

Yassaa, N., Peeken, I., Zöllner, E., Bluhm, K., Arnold, S., Spracklen, D., and Williams, J.: Evidence for marine production of monoterpenes, Environ. Chem., 5, 391-401, https://doi.org/10.1071/EN08047, 2008.

Yu, F., Ma, X., and Luo, G.: Anthropogenic contribution to cloud condensation nuclei and the first aerosol indirect climate effect, Environ. Res. Lett., 8, 024029, https://doi.org/10.1088/1748-9326/8/2/024029, 2013.

Zhang, K., Wan, H., Liu, X., Ghan, S. J., Kooperman, G. J., Ma, P.-L., Rasch, P. J., Neubauer, D., and Lohmann, U.: Technical Note: On the use of nudging for aerosol-climate model intercomparison studies, Atmospheric Chem. Phys., 14, 8631-8645, https://doi.org/10.5194/acp-14-8631-2014, 2014. 